\title{
Gasifier, Solid Oxide Fuel Cell Integrated Systems for Energy Production From Wet Biomass
}

\author{
Mayra Recalde*, Theo Woudstra and P. V. Aravind \\ Process and Energy, Delft University of Technology, Delft, Netherlands
}

Nowadays, there is worldwide interest in diversifying energy supply. In this regard, biomass is the best possible renewable organic substitute for fossil fuels. In particular, the energy content of very wet biomass, recovered with appropriate technology, could potentially be used for power generation. In addition to power generation, this technology would represent a sanitary option to improve the quality of public health and the environment. Supercritical water gasification (SCWG) is a technology applied for the conversion of wet biomass into gas. It uses the specific physical properties of water at supercritical conditions to decompose the organic matter. However, near 100\% conversion, close to thermodynamic equilibrium, of real biomass into gas is not yet demonstrated. The conversion is higher at dry biomass concentrations below $10 \mathrm{wt}$.\%,

OPEN ACCESS

Edited by:

Ligang Wang,

École Polytechnique Fédérale de Lausanne, Switzerland

Reviewed by: Rui Jing,

Xiamen University, China Theodoros Damartzis, École Polytechnique Fédérale de Lausanne, Switzerland

${ }^{*}$ Correspondence:

Mayra Recalde

mdrrecalde@gmail.com

Specialty section: This article was submitted to Process and Energy Systems

Engineering,

a section of the journal Frontiers in Energy Research

Received: 09 March 2019 Accepted: 30 October 2019 Published: 22 November 2019

Citation:

Recalde M, Woudstra T and Aravind PV (2019) Gasifier, Solid Oxide Fuel Cell Integrated Systems for Energy Production From Wet

Biomass. Front. Energy Res. 7:129. doi: 10.3389/fenrg.2019.00129 but at these conditions, the system is not energetically sustainable. The conversion depends on the SCWG operating conditions and the properties of the catalyst. Because of present-day technical limitations, the conversion efficiency in SCWG is low when fed with real biomass. The net electrical efficiency of a combined system SCWG-solid oxide fuel cell (SOFC), fed with fecal sludge at 15 wt.\% dry biomass, reaches between 50 and $70 \%$ (thermodynamically calculated values), whereas utilizing an SCWG designed with present-day engineering gives $29-40 \%$. The SOFC fuel utilization influences the system efficiency significantly, as the processed heat available for the heat integration depends on fuel utilization. The extreme operating conditions of an SCWG-based system cause technical limitations toward reaching complete conversion during gasification. An efficient and stable catalyst is not yet available at competitive costs for low-temperature SCWG of real biomass. Intensive research in different gasification-SOFC system configurations that include the integration of complementary processes, such as the electrochemical oxidation of higher hydrocarbons or the electrochemical reduction of $\mathrm{CO}_{2}$ and $\mathrm{H}_{2} \mathrm{O}$, will increase the potential of the gasification-SOFC system for commercialization in medium scale in the future and become a technology that provides economic, environmental, and health benefits.

Keywords: SCWG, SOFC, limitations, operating conditions, moisture, efficiency

\section{INTRODUCTION}

Sustainable treatment of wet biomass such as human waste, manure, or residues of food is of high importance to public health and the energy sector. For the case of public health, eliminating fecal bacteria and viruses from soil and water is vital for a healthy community. For the energy sector, it can provide clean electric energy, which is in line with the transition toward a sustainable energy 
system. The EU Commission has proposed a greenhouse gas emission reduction of $40 \%$ utilizing market-driven renewable energy by 2030 (European Commission, 2015).

Nowadays, most of the human waste and wastewater worldwide is discharged untreated, resulting in pollution of water and soil, although fecal matter (FM) has a heating value of $25 \mathrm{MJ} / \mathrm{kg}$, dried and charred (Schuster-Wallace et al., 2015). In this regard, supercritical water gasification (SCWG) converts wet biomass without drying into methane and hydrogen-rich gas. The combustible gases are relatively clean and can feed a solid oxide fuel cell (SOFC) with limited cleaning. The operating conditions of SCWG exceed the critical point of water $\left(374.3^{\circ} \mathrm{C}\right.$ and $22 \mathrm{MPa}$ ), and its thermophysical properties help reform biomass at relatively low temperature, between 400 and $700^{\circ} \mathrm{C}$. SCW does not dissolve salts and can be separated before reaching the gasifier.

SCWG of digest sludge, 6 wt.\% dry biomass, operates with a carbon gasification efficiency (CGE) of 45.8 and $80.7 \%$ solid (phosphorus) is recovered (Boukis et al., 2017). The assistance of $\mathrm{Ru} / \mathrm{C}$ catalyst and a bed of $\mathrm{ZnO}$ on top of the gasifier to absorb sulfur and protect the catalyst from deactivation help to achieve a gas composition close to thermodynamic equilibrium.

\section{SCWG Overview}

The SCWG converts a wet feedstock like sewage sludge and manure (moisture content $>50$ wt.\%) into a combustible gas. The thermophysical properties of SCW are favorable to dissolve organic matter. The low viscosity provides better mass transfer, the low density promotes better solvation properties, and the low dielectric constant makes SCW a non-polar solvent. The high ion production in SCW makes it act like an acid or base catalyst in reactions. Many organic chemicals may readily react under the hydrothermal conditions of SCW (Oka and Koshizuka, 1993; Basu and Mettanant, 2009), but inorganic does not react. Hence phosphorus, potassium, and a lower percentage of $\mathrm{Ca}, \mathrm{Mg}, \mathrm{Fe}, \mathrm{Al}$ are easily separated (Boukis et al., 2017).

Furthermore, thermophysical properties of SCW are of high significance for heat transfer and biomass gasification (Oka and Koshizuka, 1993). Above the critical pressure, there is no phase change. The change in specific heat near the critical point reaches a maximum; at this point, the recovery of heat is efficient (Oka and Koshizuka, 2001). Thus, the SCWG process usually comprises a heat recovery unit.

The basic understanding of the chemistry of SCW has been possible because of the experimental investigation using model compounds. SCWG is a process kinetically driven, and the measured gas composition often is far away from the calculated equilibrium composition (Kruse, 2008). Good approximations by thermodynamic equilibrium are only possible at high temperatures with or without a catalyst.

The SCWG process converts the large molecules of biomass into smaller gas molecules. The challenge with this process is to reach a near $100 \%$ conversion (thermodynamic equilibrium). Nevertheless, a real SCWG system operated with the presentday technologies encounters engineering limitations, restricting the conversion of organic matter into gas and other byproducts, such as char and higher hydrocarbons (hence the use of catalysts). The operating conditions, such as biomass concentration, pressure, temperature, reactor residence time, type of reactor, and catalyst, influence the conversion and the composition of the produced gas. The operation conditions should be carefully selected during the design of SCWGs for commercial application (Basu and Mettanant, 2009; Yakaboylu et al., 2015a). Although technical and economic evaluation indicates that SCWG of sewage sludge for combustible gas production is feasible (He et al., 2014), there are still challenges to overcome, associated with high operating cost, reactor plugging, and catalyst deactivation. SCWG could be acceptable for largescale commercialization in the future with the development of efficient and stable catalysts at competitive costs (Guo et al., 2010). Besides, the recovery of high-quality heat applied to the reactor under supercritical conditions is very important. Feng et al. (2004) reported a thermal energy recovery of $41 \%$.

\section{The Influence of the Operating Conditions on the Design of an SCWG Hydrothermal Process}

The hydrothermal process (biomass conversion) is given in Figure 1. Hydrothermal carbonization generates hydrochar from wet biomass at mild temperatures and pressures (Tekin et al., 2014). The gasification process avoids the operating conditions of carbonization. Below the critical point of water, liquefaction hydrolyzes biomass into smaller molecules of acids and phenols. At high temperature, the liquefaction products are reformed and gasified into smaller molecules of $\mathrm{CO}, \mathrm{H}_{2}, \mathrm{CH}_{4}, \mathrm{CO}_{2}$, and so on (Peterson et al., 2008). The pressure and temperature in the liquefaction process must be sufficient to keep the water in a liquid state. The liquid products are often called bio-oil (water-soluble components).

At near-critical temperatures up to about $400^{\circ} \mathrm{C}$, effective reforming and gasification generally require catalytic enhancement to achieve reasonable rates and selectivity to hydrogen and methane. Homogeneous gasification takes place above $400^{\circ} \mathrm{C}$ and higher pressure, producing methane or hydrogen gases in higher yields (Peterson et al., 2008; Toor et al., 2011). High temperatures $>500^{\circ} \mathrm{C}$ generate hydrogen-rich gas without catalyst or with non-metal catalysts, while at a temperature around $500^{\circ} \mathrm{C}$ with catalyst, methane-rich gas is produced.

Biomass is a combination of several components: cellulose, hemicellulose, proteins, lignin, and inorganic. During the hydrothermal process, these components interact with each other, leading to very complicated chemistry. The kinetics of the liquefaction and gasification of these components are being investigated for around 30 years. Some kinetic parameters and reaction pathways are summarized by Yakaboylu et al. (2015c). According to the results obtained from a kinetic model, higher residence time increases the CGE (Yakaboylu et al., 2015d).

\section{Influence of the Salts}

Some salts present in the biomass benefit the conversion in subcritical water, but others poison the heterogeneous catalyst at supercritical conditions, plugging by salt deposition due to the low salt water solubility. On the contrary, alkali salts are active 


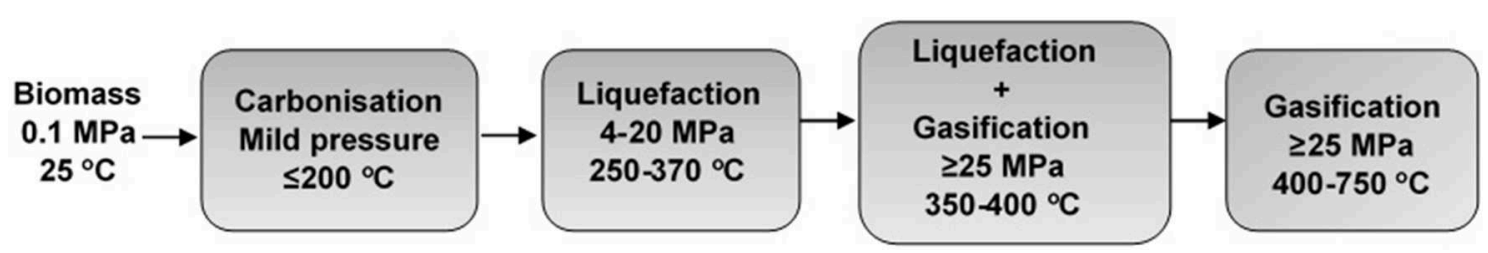

FIGURE 1 | Biomass hydrothermal conversion in a typical process configuration.

catalysts for the water-gas shift reaction (Kruse and Faquir, 2007; Maurice Henri, 2007). Only in the presence of such salts are high hydrogen yields at reasonable reaction times possible. The salts influence the reaction pathways during biomass conversion; the probable cause is the basicity of the salts. At ambient conditions, they are neutral, and at near- and supercritical water, the basicity of salts becomes very complex, as presented by Kruse and Dinjus (2005).

\section{Influence of the Pressure and Temperature}

A simplified explanation of $\mathrm{H}_{2}$ or $\mathrm{CH}_{4}$ production from the conversion of biomass into gas in SCWG is given by the stoichiometric Equations (1)-(4) (Rodriguez Correa and Kruse, 2018). The formation of $\mathrm{H}_{2}$ predominates over that of $\mathrm{CH}_{4}$ at high temperature because high temperature favors endothermic reactions Equations (1) and (2), while low temperature favors exothermic reactions Equations (3) and (4). The increasing pressure decreases the yield of $\mathrm{H}_{2}$, whereas that of $\mathrm{CH}_{4}$ increases. Besides, from simultaneous effects of temperature and pressure on hydrothermal gasification of glucose, the CGE increased with the increasing temperature and decreased with increasing pressure (Gökkaya et al., 2016).

Hydrogen formation

$$
\begin{aligned}
& \mathrm{C}_{6} \mathrm{H}_{12} \mathrm{O}_{6}+6 \mathrm{H}_{2} \mathrm{O} \rightarrow 6 \mathrm{CO}_{2}+14 \mathrm{H}_{2} \\
& \mathrm{CO}+\mathrm{H}_{2} \mathrm{O} \leftrightarrow \mathrm{CO}_{2}+\mathrm{H}_{2}
\end{aligned}
$$

Methane formation

$$
\begin{array}{r}
\mathrm{C}_{6} \mathrm{H}_{12} \mathrm{O}_{6} \rightarrow 3 \mathrm{CH}_{4}+3 \mathrm{CO}_{2} \\
\mathrm{CO}+3 \mathrm{H}_{2} \leftrightarrow \mathrm{CH}_{4}+\mathrm{H}_{2} \mathrm{O}
\end{array}
$$

\section{Influence of the Feed Concentration}

The feedstock moisture content influences the CGE and syngas composition. Most of the research, kinetic modeling, and experiments are done at dry biomass below to $10 \mathrm{wt} \%$ (Basu and Mettanant, 2009). CGE is low with feedstock at higher content as clarified in Equations (1) and (2) since the formation of $\mathrm{H}_{2}$ needs water. Therefore, more moderate moisture content theoretically reduces the formation of $\mathrm{H}_{2}$ and eases the formation of $\mathrm{CH}_{4}$ (Kruse, 2008) (Equations 3, 4). Complete gasification is only achievable with a dry-biomass concentration lower than $5 \mathrm{wt}$ \%, implying a further increase in operating cost (Xu et al., 2012). For example, the high heat capacity of water leads to very high heat requirements to heat the aqueous feedstock to $\geq 400^{\circ} \mathrm{C}$. Hence, the very high water content of the feedstock seems to be a significant disadvantage. On the other hand, the $\mathrm{H}_{2}$ yield of SCWG of sewage sludge, for industrial application, is only obtained with biomass concentration higher than 15 wt.\% (Guo et al., 2007). The high dry-matter content leads to a high gas production but at low CGE. High reaction temperatures are required to achieve complete gasification for feedstocks with smaller moisture fractions.

\section{Effect of the Resident Time and Type of Reactor}

Longer residence time raises the hydrogen yield and the CGE, while $\mathrm{CO}$ yield decreases, and favors the complete gasification of biomass, expected within seconds at a temperature above $600^{\circ} \mathrm{C}$ (He et al., 2014). However, temperatures higher than $600^{\circ} \mathrm{C}$ at a pressure $>20$ Mpa result in high operating costs and limitations on materials (Yakaboylu, 2016). These represent the principal obstacle to the development of this technology.

Continuous reactors operating at high flow rates and fluidized bed reactors are the ones more suitable to control plugging problems during SCWG. The fluidized bed reactor, besides, increases heat and mass transfer during gasification. However, to achieve higher gasification efficiencies, longer residence times, as well as higher reactor temperatures, are needed. Large continuous reactors give high residence times, but there are technical limitations in building such reactors. The preheating section of an SCWG experimental setup constructed with a pipe heat exchanger reaches a total length of $55 \mathrm{~m}$ (Yakaboylu et al., 2018). Furthermore, increasing the residence time by operating the SCW gasifier at low feed flow rates increases the gasification efficiency. However, if the flow rate is too low, it will cause a lack of fluidization inside the reactor, resulting in a very low gasification efficiency (Yakaboylu, 2016).

\section{Effect of the Catalyst}

The appropriate physicochemical properties of SCW help the reactions (Guo et al., 2010). Addition of suitable catalyst in SCW enhances gasification and is especially important at lower temperatures. Nevertheless, most catalysts get poisoned, and the destruction of their support takes place with real biomass.

Biomass decomposition in SCWG is investigated in numerous experimental studies. This gives limited reported data regarding the gas composition and CGE, in particular when the SCWG operates in continuous reactors with real biomass at higher 
than 10 wt.\%. According to the kinetic results of Yakaboylu et al. (2015d), the hydrothermal decomposition of biomass constituents (cellulose, hemicellulose, lignin, and protein) representing manure at 10 wt.\% dry biomass gives a CGE of $50 \%$, the reactor residence time is $60 \mathrm{~s}$ at $500^{\circ} \mathrm{C}, 25 \mathrm{MPa}$. Kinetic models in the catalytic SCWG of glucose, gives a CGE variation from 80 to $100 \%$, the feed biomass fraction is $5-35$ wt.\% (Tushar et al., 2015).

Table 1 compares the gas composition and CGE of different types of feedstock at varied operating conditions in SCWGs. The influence of the catalyst, feedstock concentration, and temperature on the CGE is visible. The CGE of glucose conversion in SCWG reaches near $100 \%$ with the assistance of a catalyst at low feedstock biomass fraction $5 \mathrm{wt} . \%$ and $500^{\circ} \mathrm{C}$. A CGE of $99.9 \%$ is achieved for simulated waste at 5 wt. $\%$ feedstock at $600^{\circ} \mathrm{C}$, with the assistance of a catalyst. The CGE of corn $+\mathrm{CMC}$ is $40 \%$ at $600^{\circ} \mathrm{C}, 15 \mathrm{wt} . \%$, and have non-assistance of a catalyst. It is noticeable that the amount of $\mathrm{CO}_{2}$ in all cases is significant.

\section{Gasifier-SOFC Integrated System}

The gas produced by gasification processes is a potential fuel for a SOFC. The SOFC converts the chemical energy of the gas into electricity. The gasification of organic waste integrated with the high-temperature electrochemical process is attractive from the thermal point of view since gasification also operates at high temperature. Heat integration allows the generation of power with a high system efficiency.

A SOFC is an electrochemical device that comprises a solid electrolyte, a fuel electrode, and an oxygen electrode. The electrolyte allows the transport of oxygen ions, and the electrodes transport charge and are a heterogeneous catalyst. A charge transfer takes place among a gas, electrolyte, and electrodes and results in fuel oxidation (Hanna et al., 2014). Fuel oxidation generates heat and electricity. Furthermore, the heterogeneous catalyst in the fuel electrode promotes the reforming and partial oxidation of hydrocarbons.

The efficiency of the SOFC system depends on the thermal strategy of the balance of the plant (BOP) and SOFC design. Processed heat must replace the external energy required for air and fuel preheating in the BOP. The SOFC exhaust gases mostly contain $\mathrm{CO}_{2}$ and $\mathrm{H}_{2} \mathrm{O}$. Potential exists for the capture and storage of these gases for further application, such as the electrochemical conversion of $\mathrm{CO}_{2}$ into $\mathrm{CO}$ (Ibram, 2018) or to feed a photobioreactor (Santarelli et al., 2017).

Thermodynamic calculations demonstrate a net electrical efficiency of $50 \%$ reached by a manure SCWG combined with a SOFC and gas turbines (GT) (Toonssen et al., 2010). The efficiency increased to $63 \%$ by integrating an SCWGSOFC-Rankine cycle-Fuel processing turbines-GT (Facchinetti et al., 2012). On the other hand, in comparison, for a plasma gasification-based plant, including a fecal sludge drier, gasifier, gas cleaning unit, and SOFC-steam turbine combined system, the net electrical efficiency reaches 65\% (Recalde et al., 2018). The efficiency calculated in these works assumed complete conversion of the chemical energy of the biomass into synthesis gas at thermodynamic equilibrium.

\section{Perspective of the SCWG SOFC}

The variation of the effectiveness of catalysts and variations in process conditions in the SCWG influence syngas compositions and quantities and hence the overall system efficiencies. Such influences are not yet studied in detail. This work, as far as the authors are aware of, for the first time, evaluates the influence of such variations on the efficiencies of SCWG integrated highefficiency power plants in which SOFCs are employed for power production.

The performance of an SCWG at different operating conditions and the thermal strategy applied to the SCWGSOFC combined system strongly influence the efficiency of the system. In particular, the combination of high temperature and high biomass moisture. Those parameters are favorable to reach almost full biomass conversion but negatively affect the thermal management and represent a challenge in the field of construction materials. On the contrary, operation of the SCWG at lower temperature and biomass moisture, expected in a real gasifier, makes it difficult to achieve complete conversion (thermodynamic equilibrium) in SCWGs. It results in lower conversion efficiency and lower production rate of syngas, which has an influence on the final results. These conditions are stopping the industrial development of the SCWG technology for the treatment of the unappealing wet biomass. Considering the mentioned drawback is compulsory to find new ways to improve the performance of an SCWGSOFC system. Therefore, this study develops a parametric analysis of the SCWG-SOFC system to determine the influence of the mentioned gasifier condition on the energy and exergy performance of the system. The energy and exergy analysis will allow identifying potential process streams to combine bottoming cycles as a possible route to improve system performance.

As a result, the performance of a fecal sludge SCWG-SOFC power plant for industrial applications depends on the gasifier design with several engineering limitations and the thermal strategy applied in the system. No high $\mathrm{H}_{2}$ purity is required for an SOFC because of the internal heterogeneous reactions achieved in an SOFC. In this work, a thermodynamic model, developed in Aspen Plus ${ }^{\mathrm{TM}}$, simulates the performance of an SCWG-SOFC power plant. Two models estimate the net electrical efficiency of the combined system, one operated with a real SCWG gasifier and another with a gasifier at thermodynamic equilibrium. Both systems are modeled according to the scheme in Figure 2, to be discussed in the next chapter. The data used in the model is from SCWG experimental plants designed with present-day engineering limitations. The current work assesses the influence of the operating conditions on the system net electrical efficiency and the impact of the SCWG operating conditions on the biomass conversion. Finally, the present work compares the system performance with the performance of another similar system, that is, a plasma-assisted two-stage 
TABLE 1 | Comparison of gas composition and carbon gasification efficiencies of various feedstock from supercritical water gasification (SCWG) and SCWG experimental investigations.

\section{Experimental results}

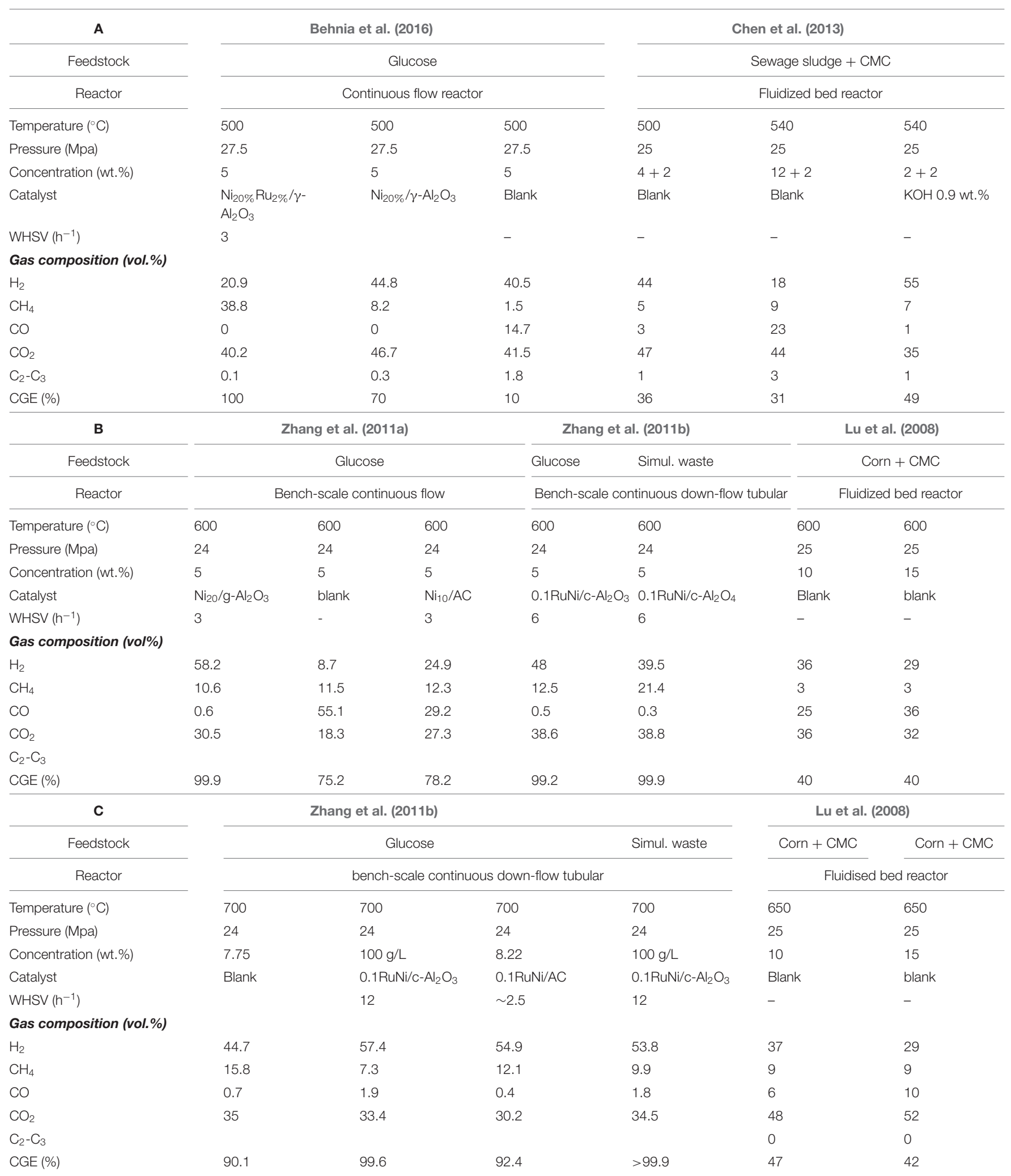




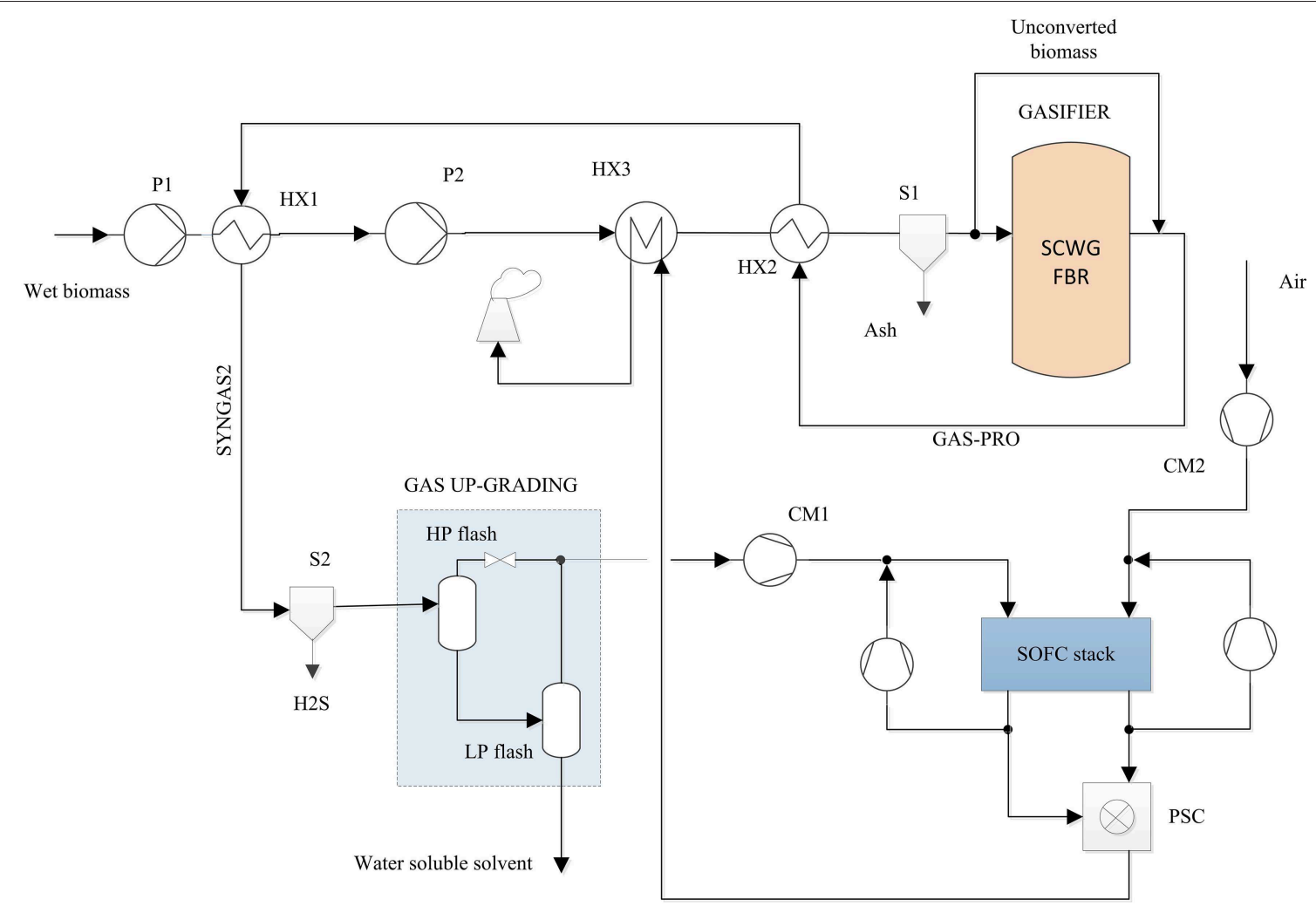

FIGURE 2 | Layout of the supercritical water gasification (SCWG)-solid oxide fuel cell (SOFC) integrated system.

gasifier-SOFC-Micro steam turbine (MST) presented by the author in a previous publication (Recalde et al., 2018).

\section{SYSTEM DESCRIPTION}

Figure 2 depicts a schematic flow sheet of the SCWG-SOFC system. Biomass at ambient conditions is pressurized in pump $\mathrm{P} 1$ and $\mathrm{P} 2$ to 12 and $25 \mathrm{MPa}$, respectively; HX1 and HX2 increase the temperature to around 110 and $320^{\circ} \mathrm{C}$, respectively.

HX3 heats the hot pressurized biomass to reach a value below the reaction temperature, around $400^{\circ} \mathrm{C}$. The flow is fed into the SCWG, where the conversion reaction is taking place at 500 or $600^{\circ} \mathrm{C}$ and $25 \mathrm{MPa}$. Unconverted biomass is sent around the reactor. The solid separator S1 removes the ash to clean the gas. $\mathrm{HX} 2$ and HX1 recover the heat of the produced gas, leaving the SCWG, to use it for biomass preheating. Then the gas is cooled down below to $200^{\circ} \mathrm{C}$ in $\mathrm{HX} 4$. The gas upgrading unit separator 1 (HP flash) at 10 bar separates fuel gas from water, which contains the higher hydrocarbons. Further separations take place in LP flash at $25^{\circ} \mathrm{C}$ and low pressure of 1 bar. The fuel gas contains $\mathrm{CH}_{4}, \mathrm{H}_{2}, \mathrm{CO}$, and a small concentration of $\mathrm{CO}_{2}$ and $\mathrm{H}_{2} \mathrm{O}$.

The gas cleaning unit S2 removes $\mathrm{H}_{2} \mathrm{~S}$ from the upgraded gas at ambient conditions. The clean syngas is fed with steam, then is heated up to $850^{\circ} \mathrm{C}$ with recirculated syngas and fed into the SOFC anode. Internal reforming of $\mathrm{CH}_{4}$ will take place in the SOFC anode. Air is heated to $650^{\circ} \mathrm{C}$ with the exhaust gas from the SOFC cathode post-stack combustor (PSC) and fed into the SOFC cathode. The SOFC stack converts a large part of the chemical energy of syngas into electricity and heat. The PSC combusts the exhaust gas from the SOFC anode with the air from the cathode exhaust. Then, the flue gases heat the hot pressurized biomass in HX3.

\section{THERMODYNAMIC MODEL}

Reactions (1)-(4) explain the complete conversion of biomass in SCWG, where $\mathrm{C}_{6} \mathrm{H}_{12} \mathrm{O}_{6}$ represents biomass.

The reactions that might occur in a SOFC anode operated with syngas are the oxidation of fuel, Equation (5); the watergas shift reaction, Equation (6); the internal steam reforming of fuel Equation (7). The electrochemical conversion of the fuel is carried out according to reactions Equations (5) and (9), generating electrical energy and heat [the heat given is for both Equations (5) and (8)].

At the fuel electrode

$$
\begin{aligned}
& \mathrm{H}_{2}+1 / 2 \mathrm{O}^{2-} \rightarrow \mathrm{H}_{2} \mathrm{O}+2 \mathrm{e}^{-} \Delta h=-242 \mathrm{~kJ} / \mathrm{mol} \\
& \mathrm{H}_{2} \mathrm{O}+\mathrm{CO} \leftrightarrow \mathrm{H}_{2}+\mathrm{CO}_{2} \Delta h= \pm 41 \mathrm{~kJ} / \mathrm{mol} \\
& \mathrm{CH}_{4}+\mathrm{H}_{2} \mathrm{O}_{(\text {gas })} \leftrightarrow 3 \mathrm{H}_{2}+\mathrm{CO} \Delta h= \pm 206 \mathrm{~kJ} / \mathrm{mol}
\end{aligned}
$$


At the oxidant electrode

$$
\mathrm{O}^{2-}+4 \mathrm{e}^{-} \rightarrow 2 \mathrm{O}^{2-}
$$

\section{Energy and Exergy Analysis of the SOFC}

Equation (9) determines the power and heat generated by the reactions $(5,6)$, where $\Delta H$ is the change of enthalpy, $T$ is the reaction temperature, $\Delta S$ is the change of entropy, TS is the heat, and $\Delta \mathrm{G}$ is the Gibbs free energy change, giving the power (O'Hayre et al., 2016).

$$
\Delta \mathrm{H}=\Delta \mathrm{G}+\mathrm{TS}
$$

The reversible cell voltage of the SOFC refers to the transfer of charged species, electrons, or ions across the interface in a SOFC and is given by Equation (10). Where $n$ describes the number of moles of electrons transferred for every mole of chemical species reacting, and F is Faraday's constant.

$$
\mathrm{E}=-\frac{\Delta \mathrm{G}}{\mathrm{nF}}
$$

The Nernst equation describes the reversible cell voltage of the SOFC as a function of the partial pressure of the system species, applied to the chemical reactions Equations (5) and (8) gives:

$$
\mathrm{E}_{\mathrm{r}}=\mathrm{E}+\frac{\mathrm{RT}}{\mathrm{nF}} \frac{\mathrm{P}_{\mathrm{H}_{2}} \mathrm{P}_{\mathrm{O}_{2}}^{1 / 2}}{\mathrm{P}_{\mathrm{H}_{2} \mathrm{O}}}
$$

During operation, the resistance to the flow of an electric current in the cell generates Ohmic overpotential $\eta_{\text {ohm }}$. Additionally, the charge transfer reactions cause activation overpotential $\eta_{\text {act }}$, and the transport limitations of gases through the porous electrodes to the TPB cause concentration/diffusion overpotentials $\eta_{\text {conc }}$. The total overpotential reduces the final voltage of the cell, being a function of the current density $j$

$$
\mathrm{V}_{\mathrm{SOFC}}=\mathrm{E}_{\mathrm{r}}-\eta_{\text {act }}(\mathrm{j})-\eta_{\mathrm{ohm}}(\mathrm{j})-\eta_{\text {conc }}(\mathrm{j})
$$

The cell resistance of an electrolyte-supported SOFC is governed mainly by the Ohmic type overpotentials, which depends mostly on the cell temperature. In this work, the SOFC temperature is assumed constant. Hence, the polarization overpotential is constant and is represented by the area specific resistance of the cell (ASR)

$$
\mathrm{V}_{\mathrm{SOFC}}=\mathrm{E}_{\mathrm{r}}-\mathrm{ASR}(\mathrm{j})
$$

Faraday's Law, Equation (14), describes the maximum current that a SOFC generates. Assuming the electrochemical oxidation of $\mathrm{H}_{2}$ and the internal reforming of $\mathrm{CH}_{4}$ and $\mathrm{CO}$ :

$$
\begin{aligned}
& \mathrm{I}_{\mathrm{SOFC}}=2 \bullet \mathrm{F} \bullet \mathrm{N}_{\text {fuel }} \bullet \mathrm{U}_{\mathrm{f}} \\
& \mathrm{N}_{\text {fuel }}=2 \bullet \mathrm{N}_{\mathrm{H}_{2}}+8 \bullet \mathrm{N}_{\mathrm{CH}_{4}}+2 \bullet \mathrm{N}_{\mathrm{CO}}
\end{aligned}
$$

where the $\mathrm{N}_{\text {fuel }}\left[\mathrm{mol} . \mathrm{s}^{-1}\right.$ ] is the moles of reactants on SOFC, and $\mathrm{U}_{\mathrm{f}}$ is the fuel utilization for the requirements of an excess of fuel to avoid $\mathrm{Ni}$ oxidation.
The current density result:

$$
\mathrm{j}_{\mathrm{SOFC}}=\frac{\mathrm{I}_{\mathrm{SOFC}}}{\mathrm{ASOFC}_{\mathrm{SOC}}}
$$

where $A_{\text {ReSOC }}$ is the area of the stack. The oxygen usage is calculated considering that each mole of oxygen transfers four moles of electrons:

$$
\mathrm{O}_{2} \text { usage }=\frac{\mathrm{I}_{\mathrm{SOFC}}}{4 \mathrm{~F}} \text { moles s}^{-1}
$$

The power of the SOFC is calculated by:

$$
\mathrm{P}_{\mathrm{SOFC}}=\mathrm{V}_{\mathrm{SOFC}} \bullet \mathrm{I}_{\mathrm{SOFC}}
$$

From the energy balance Equation (19) describes the heat generated by the SOFC, where $\Delta h_{\mathrm{CH}_{4}}, \Delta h_{W G S}$ are the reaction enthalpies of the SOFC anode heterogeneous reactions: respectively, methanation and water gas shift reaction; the term $\eta_{\text {SOFC }} \mathrm{I}$ is the heat generated by the cell overpotential, which is equal to the ASR times the current I $[\mathrm{kW}]$. The enthalpy of the oxidant flow rate (in general air), $\Delta \mathrm{h}_{\mathrm{Ox}}$, fed to the SOFC cathode, acts as temperature regulator removing the excess heat from the SOFC. $\mathrm{N}$ is mol flow rate of the chemical species:

$$
\begin{aligned}
\dot{\mathrm{N}}_{\mathrm{mol}, \mathrm{ox}} \bullet \Delta \mathrm{h}_{\mathrm{ox}}= & \dot{\mathrm{N}}_{\mathrm{mol}, \mathrm{H}_{2}} \bullet \mathrm{T} \Delta \mathrm{S}+\left(\dot{\mathrm{N}}_{\mathrm{mol}_{, \mathrm{CH}}} \bullet \Delta \mathrm{h}_{\mathrm{CH}_{4}}\right. \\
& \left.+\dot{\mathrm{N}}_{\mathrm{mol}, \mathrm{CO}} \bullet \Delta \mathrm{h}_{\mathrm{WGS}}+\eta_{\mathrm{SOFC}}\right)
\end{aligned}
$$

\section{Exergy Analysis of System}

The exergy analysis estimates the work obtained from the SCWGSOFC system and determines the components where the exergy destruction and losses take place.

The exergy balance (Moran, 2017) of the SCWG-SOFC at steady state is represented by Equation (20). The exergy enters the system with the biomass. The system is well insulated; in this regard, there is no exergy transfer accompanying heat transfer (except by the GUP), and the SOFC generates power:

$$
0=-\mathrm{E}_{\mathrm{r}}+\sum_{i} \dot{\mathrm{m}}_{\mathrm{ie}_{\mathrm{fi}}}-\sum_{\mathrm{e}} \dot{\mathrm{m}}_{e} \dot{\mathrm{e}}_{\mathrm{fe}}-\dot{\mathrm{E}}_{\mathrm{d}}
$$

where $\dot{E}_{d}$ is the rate of exergy-destruction within the system, $\mathrm{e}_{f}$ is the total specific flow exergy at inlet $i$, and $e_{f e}$ is the specific flow exergy at exit e.

$$
\dot{\mathrm{e}}_{\mathrm{f}}=\mathrm{h}-\mathrm{h}_{0}-\mathrm{T}_{0}\left(\mathrm{~s}-\mathrm{s}_{0}\right)+\mathrm{e}^{\mathrm{ch}}
$$

where $h$ and $s$ represent the specific enthalpy and entropy, respectively, at the inlet or exit under consideration; $h_{0}$ and $s_{0}$ are the properties at the reference conditions $\mathrm{T}_{0}, \mathrm{p}_{0}$

The chemical exergy for an ideal gas mixture at $\mathrm{T}_{0}, \mathrm{p}_{0}$, is given by:

$$
\bar{e}^{\mathrm{ch}}=\sum_{\mathrm{i}=1}^{\mathrm{j}} \mathrm{y}_{\mathrm{i}} \overline{\mathrm{e}}_{\mathrm{i}}^{\mathrm{ch}}+\overline{\mathrm{R}} \mathrm{T}_{0}\left(\sum_{\mathrm{i}=1}^{\mathrm{j}} \mathrm{y}_{\mathrm{i}} \ln \mathrm{y}_{\mathrm{i}}\right)
$$

where $\mathrm{e}_{\mathrm{i}}^{\mathrm{ch}}$ is the chemical exergy for each gas component $i$, and $\mathrm{y}_{\mathrm{i}}$ denotes the mole fraction of component $i$ in the mixture. 


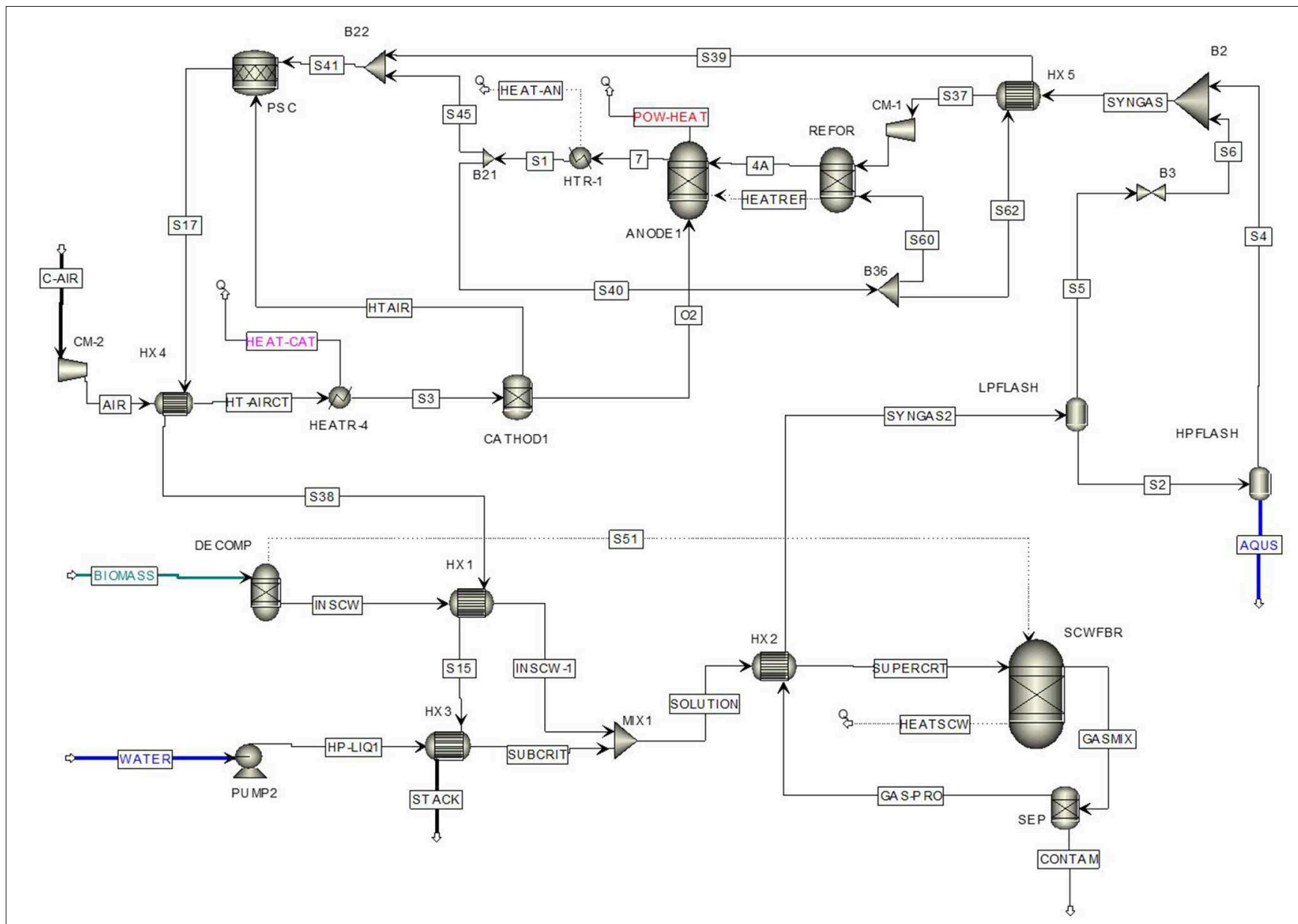

FIGURE 3 | Aspen Plus process flow diagram of the supercritical water gasification (SCWG)-solid oxide fuel cell (SOFC) system.

\section{Efficiencies}

Equation (23) defines the net electrical efficiency of the power plant $\eta$ el, where $\mathrm{P}_{\mathrm{SOFC}}$ is the electricity generated by the SOFC stack $(\mathrm{kW}), \mathrm{P}_{\mathrm{BOP}}$ is the total power consumption of auxiliary components, including compressors and pumps $(\mathrm{kW}) ; \dot{m}_{\text {biomass }}$ is the mass flow of the biomass fed into the system $\left(\mathrm{kg} \mathrm{s}^{-1}\right)$; LHV (dry) biomass is the lower heating value of the biomass on a dry basis $\left(\mathrm{kJkg}^{-1}\right)$.

$$
\eta_{\mathrm{el}}=\frac{\dot{\mathrm{P}}_{\mathrm{SOFC}}-\dot{\mathrm{P}}_{\mathrm{BOP}, \text { sys }}}{\dot{\mathrm{m}}_{\text {biomass }} \times \mathrm{LHV}_{\text {biomass }}}
$$

The exergy efficiency $\eta_{\text {ex }- \text { sys }}$ is the ratio between the power generated in the SOFC exergy minus the BOP of the system and the exergy in the biomass.

$$
\eta_{\mathrm{ex}-\mathrm{sys}}=\frac{\dot{\mathrm{P}}_{\mathrm{SOFC}}-\dot{\mathrm{P}}_{\mathrm{BOP}, \mathrm{sys}}}{\dot{\mathrm{m}}_{\text {biomass }} \times \mathrm{Ex}_{\mathrm{biomass}}}
$$

The CGE is the ratio of the total amount of carbon in the gas phase divided to the total amount of carbon in the feedstock, where $\mathrm{N}_{C}$ is the mole of carbon.

$$
\text { CGE }=\frac{\dot{\mathrm{N}}_{\text {C.syngas }}}{\dot{\mathrm{N}}_{\text {C,biomass }}}
$$

\section{ASPEN MODEL}

Figure 3 illustrates the Aspen model of the SCWG-SOFC system. The equation of state Peng Robinson is applied in the Aspen model because it is more favorable for describing thermodynamic behavior at temperatures above the critical point of water. The SCWG model utilizes processes with solids according to the procedure presented in Aspen Plus (2012), represented by the reactors DECOMP and SCWG. The SCWG product gas composition at thermodynamic equilibrium is calculated by applying the Gibbs free energy minimization method using the Gibbs Reactor in Aspen Plus ${ }^{\text {TM }}$. The gasifier at non-thermodynamic equilibrium uses the RYield Reactor in Aspen Plus ${ }^{\mathrm{TM}}$. The gas upgrading unit (GUP), modeled by the HPFLASH and LPFLASH, separates the unconverted components from the gas, which are water-soluble (acetic acid as a representative component for the present models). 
The present SOFC model was built based on the work of Tanim et al. (2013, 2014) and Zhang et al. (2005). Gibbs reactor REFOR describes the heterogeneous reaction WGSR, the electrochemical oxidation of $\mathrm{H}_{2}$ with the Gibbs reactor ANODE1. The heat and power produced by ANODE-1 is calculated by applying a calculator block; the total value describes the POWHEAT stream. The air flow rate represented by the C-AIR stream carries the heat generated in ANODE-1, calculated by Equation 18. The stream HEAT-CAT takes the heat to the CATH, modeled as a Flash in Aspen. The C-AIR flow rate changes to maintain the $\mathrm{SOFC}$ system isothermal at $850^{\circ} \mathrm{C}$. The molar flow rate of stream $\mathrm{O}_{2}$ is calculated by Equation 16 .

\section{RESULTS AND DISCUSSION}

\section{Model Comparison}

Figure 4A compares the SCWG syngas composition reported by the experimental work of Boukis et al. (2017) with the calculated gas composition at thermodynamic equilibrium, temperature $450^{\circ} \mathrm{C}, 25 \mathrm{MPa}, 6.7 \mathrm{wt} . \%$ dry biomass concentration. The difference in gas concentrations might be due to the experimental results presented by Boukis that gives a CGE of $45.8 \%$; this generally occurs in SCWG real systems due to the natural constraints (Kozeschnik, 2000), according to Yakaboylu et al. (2015a). The CGE is the most essential additional constraint that might affect the gas composition. The presence of $\mathrm{CO}$ at temperatures lower than $500^{\circ} \mathrm{C}$ is the result of the insufficient residence time to complete the water gas shift reaction (Yakaboylu et al., 2018).

The simulation results of the SCWG-SOFC system are compared with the simulation data reported by Facchinetti et al. (2012). Table 2 gives the input parameters and the results. The syngas chemical composition, in dry basis, is comparable in both works. The different operating conditions of the GUP result in a higher content of $\mathrm{H}_{2} \mathrm{O}$ on the syngas composition presented by Facchinetti, operating the GUP at 70 and 1-6 bar. Whereas, in this work, the operating pressures are 10 and 1 bar. In general, the SCWG-SOFC system performance has a good agreement with the reported value.

\section{Analysis of the Process Parameters}

This section presents the results of the thermodynamic analysis of the proposed system. The impact of temperature and biomass moisture, SOFC fuel utilization, and CGE on system performance is investigated. The feedstock used for this analysis is fecal sludge. Table 3 gives the ultimate analysis. Table 4 gives the SCWG and SOFC operating conditions.

\section{SCWG-SOFC Influence of Fuel Utilization and Biomass Moisture Content on the Net Electrical and Exergy Efficiency}

The product gas at thermodynamic equilibrium, temperature 500 and $600^{\circ} \mathrm{C}$ and 250 bar is illustrated in Figures 4B, C. The significant increment of $\mathrm{H}_{2}$ and reduction of $\mathrm{CH}_{4}$ concentrations at biomass water content higher than 85 wt.\% are noticeable. Figure 5 shows the net electrical and exergy efficiency of the

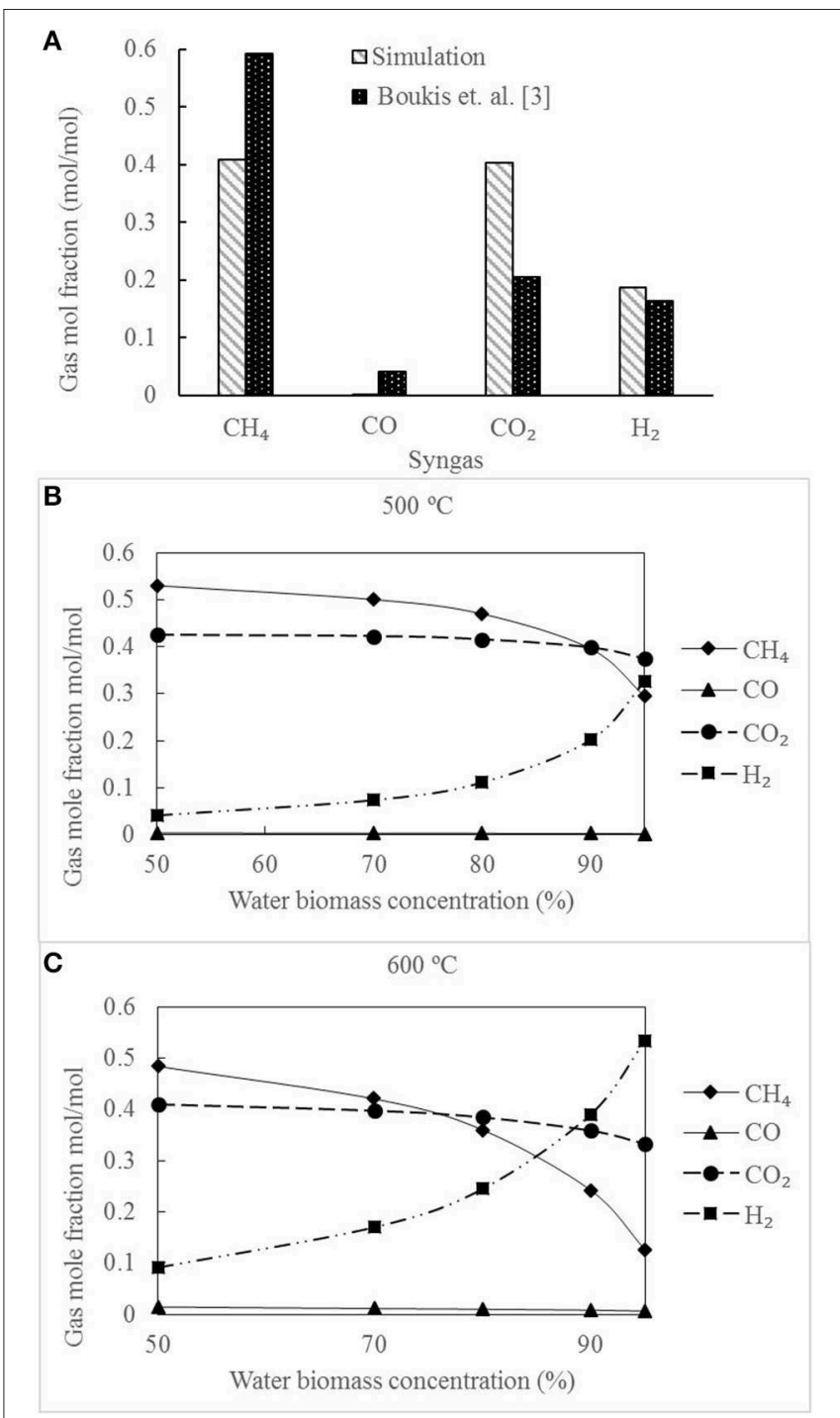

FIGURE 4 | (A) Product gas composition compared with reference gas product concentration at reactor temperature $450^{\circ} \mathrm{C}$, pressure is $25 \mathrm{MPa}, 6.7$ wt.\% moisture content at thermodynamic equilibrium (TE) and at non-equilibrium. (B) Product gas composition vs. biomass moisture and SCWG temperature at $500^{\circ} \mathrm{C}$ and $(\mathbf{C})$ at $600^{\circ} \mathrm{C}$.

SCWG-SOFC system as a function of SOFC $\mathrm{U}_{\mathrm{f}}$ (fuel utilization) and biomass moisture content.

The system net electrical efficiency is maximum at higher $U_{f}$ and low biomass moisture content. $\mathrm{U}_{\mathrm{f}}$ variation from 0.65 to 0.95 changes the net electrical efficiencies from 56 to $72 \%$ at moisture content 80 wt.\%, and from 13.4 to $46 \%$ at 95 wt.\%. Higher $\mathrm{U}_{\mathrm{f}}$ generates additional power and heat in the SOFC, and the heat efficiently preheats the air and fuel inlet streams. Also, high $\mathrm{U}_{\mathrm{f}}$ reduces the fuel fed to the PSC, and thus the exhaust gases that preheat the feedstock entering the SCWG, leading to lower exergy destruction, because of the reduction of the temperature difference between the streams. The highest net electrical efficiency and exergy efficiencies of 72 and 59\%, 
TABLE 2 | Comparison of the simulation results of the supercritical water gasification (SCWG)-solid oxide fuel cell (SOFC) system with the data obtained from reference.

\begin{tabular}{lll}
\hline Parameter & $\begin{array}{l}\text { Facchinetti } \\
\text { et al. (2012) }\end{array}$ & \\
\hline
\end{tabular}

\section{SCWG}

\begin{tabular}{|c|c|c|c|}
\hline Feedstock composition & $(\mathrm{C}, \mathrm{H}, \mathrm{O}, \mathrm{N})$ & \multicolumn{2}{|c|}{$51.1,5.8,42.9,0.2$} \\
\hline $\begin{array}{l}\text { Dry biomass } \\
\text { concentration }\end{array}$ & wt. \% & \multicolumn{2}{|c|}{80} \\
\hline Pressure & bar & \multicolumn{2}{|c|}{300} \\
\hline Temperature & ${ }^{\circ} \mathrm{C}$ & \multicolumn{2}{|c|}{400} \\
\hline $\begin{array}{l}\text { Syngas chemical } \\
\text { composition }\end{array}$ & \multicolumn{3}{|l|}{$\mathrm{m} . \%$} \\
\hline $\mathrm{H} 2$ & & 1.5 & 1.7 \\
\hline $\mathrm{CH} 4$ & & 33.6 & 44.7 \\
\hline $\mathrm{H} 2 \mathrm{O}$ & & 34.3 & 10.1 \\
\hline $\mathrm{CO} 2$ & & 30.6 & 43.5 \\
\hline $\mathrm{CO}$ & & - & 0.0 \\
\hline \multicolumn{4}{|l|}{ SOFC } \\
\hline Pressure & bar & 1.0 & 1.0 \\
\hline Temperature & ${ }^{\circ} \mathrm{C}$ & $800 ; 850$ & 850 \\
\hline Fuel utilization & & $0.7 ; 0.8$ & 0.8 \\
\hline SOFC efficiency & $\%$ & 62.2 & 58.2 \\
\hline \multicolumn{4}{|l|}{ SCWG-SOFC } \\
\hline Net electrical efficiency & $\%$ & 49.5 & 50.3 \\
\hline Exergy efficiency & $\%$ & 47.8 & 47.8 \\
\hline
\end{tabular}

TABLE 3 | Ultimate analysis of fecal sludge.

\begin{tabular}{lc}
\hline Ultimate analysis (wt. \%-dry basis) & \\
\hline H & 6.3 \\
C & 42.96 \\
N & 2.36 \\
S & 0.10 \\
O (by difference) & 35.78 \\
Ash & 12.50 \\
Moisture (\%) & 85 \\
Energy content LHV (dry) (MJ/kg) & 16.84
\end{tabular}

respectively, are obtained at 80 wt.\% moisture, $\mathrm{U}_{\mathrm{f}} 0.95$. The efficiencies decrease significantly to 46 and $39 \%$ at 95 wt.\%, since extra heat is required to maintain the reaction temperature, due to the significant increment of water fed to the system.

For lower moisture content in the biomass, the SOFC off gas, after combustion, provides enough heat for gasification but at the expense of reducing SOFC $\mathrm{U}_{\mathrm{f}}$ to 0.65 and consequently decreasing the SOFC power generation. On the other hand, the hot syngas efficiently preheats biomass by the recovery of the high-quality heat produced in SCW. The higher moisture in the biomass favors the $\mathrm{H}_{2}$ production. However, the influence in the chemical exergy is minor; at $95 \mathrm{wt} . \%$, the chemical exergy of syngas after the GPU reaches $9,499 \mathrm{~kW}$ and decreases to 9,342 kW at 80 wt.\%.
TABLE 4 | Gasifier and solid oxide fuel cell (SOFC) stack parameter and operating conditions.

\section{Parameters and Operating Conditions}

\section{Supercritical water gasification (SCWG)}

Reaction temperature

Reaction pressure

Dry biomass flow rate

$\begin{array}{cc}{ }^{\circ} \mathrm{C} & 500-600 \\ \mathrm{MPa} & 25 \\ \mathrm{~g} / \mathrm{s} & 0.56 \\ \mathrm{wt} \% & 20-5 \\ \mathrm{bar} & 10-1 \\ { }^{\circ} \mathrm{C} & 100-25 \\ \% & 80\end{array}$

HP-LP flash pressure (Yakaboylu et al., 2015b)

HP-LP flash temperature (Yakaboylu

et al., 2015b)

Pump efficiency (Chen et al., 2019)

\section{SOFC}

Number of cells

Area of a cell

Fuel utilization $U_{f}$

Current density

Cell resistance (Ilbaş and Kümük, 2019)

Operating temperature

Operating pressure

DC-AC inverter efficiency

Fuel compressor isentropic efficiency

(Yan et al., 2013)

Air compressor isentropic efficiency

Minimum approach temperature

$\begin{array}{cc}- & 371 \\ \mathrm{~m}^{2} & 0.01 \\ - & 0.65-0.95 \\ \mathrm{~A} / \mathrm{m}^{2} & 2,000- \\ & 2,500 \\ \Omega \mathrm{m} & 5 \mathrm{e}-5 \\ { }^{\circ} \mathrm{C} & 850 \\ \mathrm{bar} & 1.013 \\ \% & 95 \\ \% & 82 \\ \% & 82 \\ \mathrm{~K} & 10\end{array}$

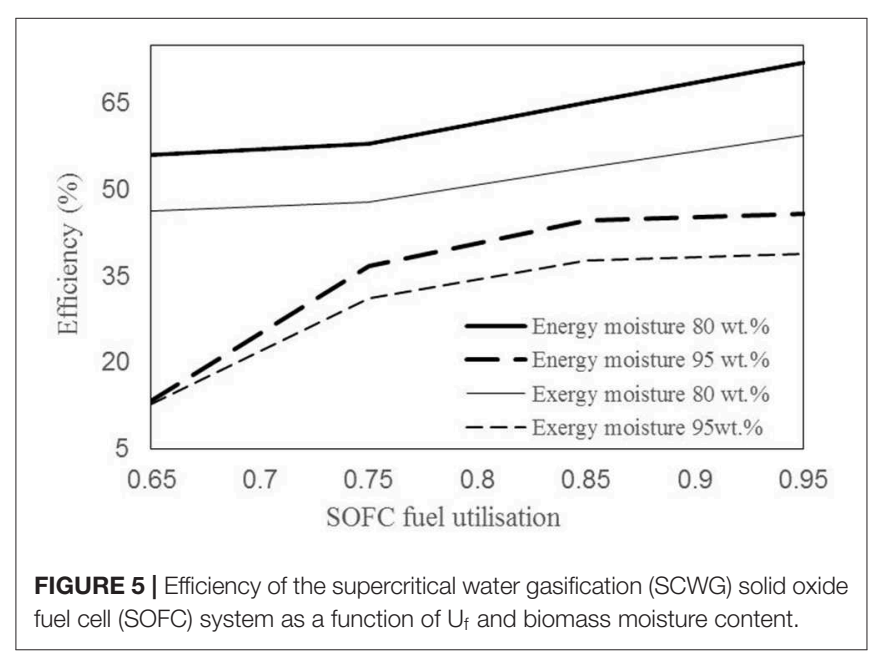

Figure 6A illustrates the contribution of each process unit in the exergy destruction at 80 and $95 \mathrm{wt} . \%$ biomass moisture. The most significant contributions are from SOFC-air preheater, SCWG, gas GUP, and fuel preheater. The total exergy destruction is higher in the case of higher biomass moisture content at 95 wt.\% because of the significant increase in exergy losses in the SCWG. The SCWG exergy destruction increases from $1,054 \mathrm{~kW}$ at $80 \mathrm{wt} . \%$ to $2,335 \mathrm{~kW}$ at $95 \mathrm{wt} . \%$. The high exergy destruction in the SCWG is principally caused by variations in the thermochemical exergy. The chemical exergy has a lower influence (changes from 9.3 MW at $80 \mathrm{wt} . \%$ to $9.5 \mathrm{MW}$ at 95 


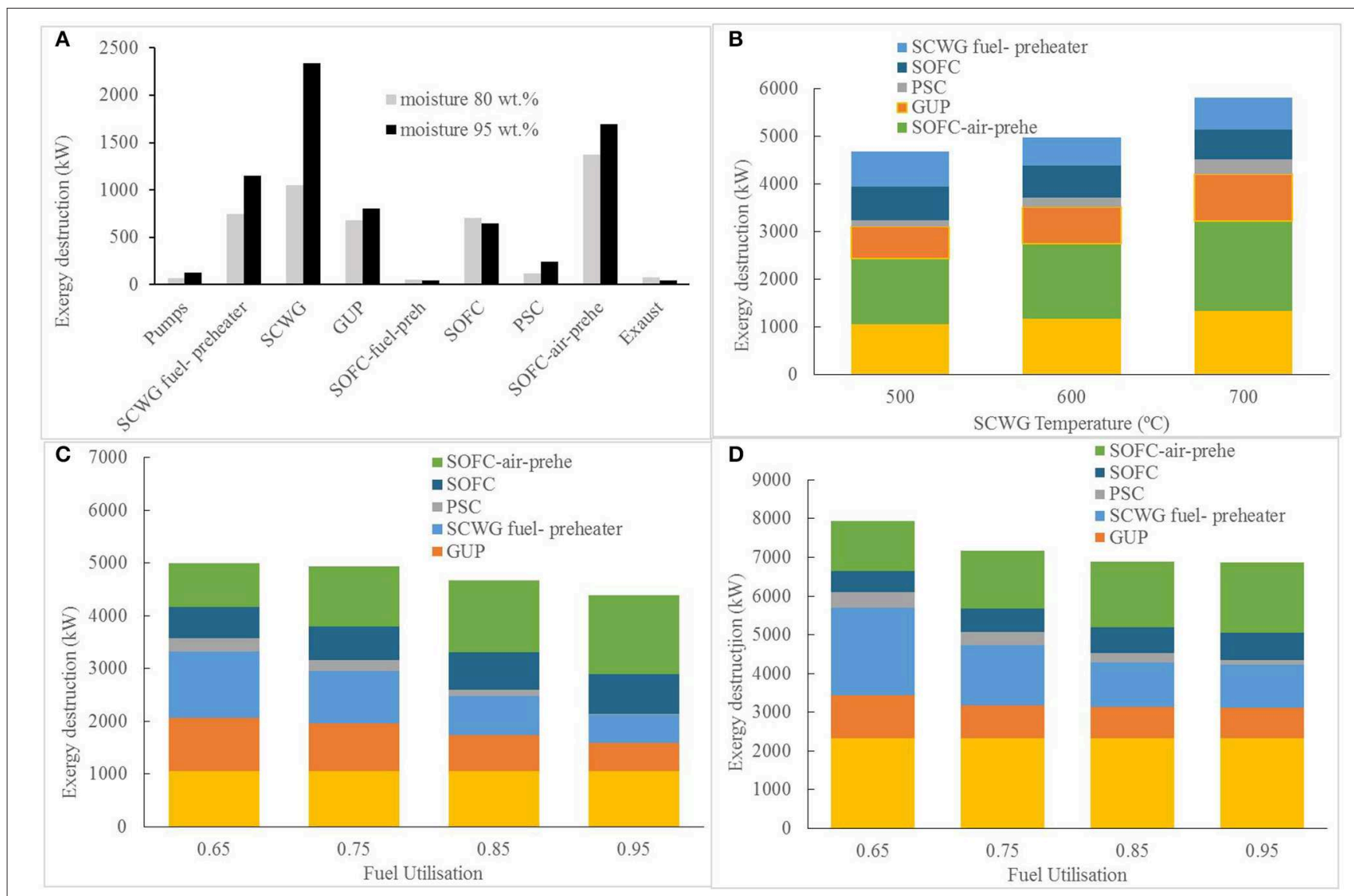

FIGURE 6 | Exergy destruction attribution of each section to the total exergy loss as a function of: (A) 80 and 95 wt.\% biomass moisture (B) gasifier temperature (C) $\mathrm{U}_{\mathrm{f}}$ in supercritical water gasification (SCWG)-solid oxide fuel cell (SOFC) system at $80 \mathrm{wt}$ \% and (D) $\mathrm{U}_{\mathrm{f}}$ in SCWG-SOFC system at $95 \mathrm{wt} \%$.

wt.\%; Figure 9). Irreversibilities in the SOFC-air processing and fuel processing are associated with the heat transfer between the high- and low-temperature fluids in the heat exchangers. Exergy destruction in the air compressor and pumps is considerably lower. Exergy loss occurs in the GUP (Figure 2) due to heat transfer. The water separation is an exothermic process, and thus heat is transferred from the HP flash to the surroundings. LP flash operates at ambient temperature, $25^{\circ} \mathrm{C}$, and the exergy loss is negligible. The exergy destruction in the fuelprocessing unit is higher at $95 \mathrm{wt} . \%, 1,153 \mathrm{~kW}$ when compared to $390 \mathrm{~kW}$ at $80 \mathrm{wt} . \%$. Higher water flow rate at increased biomass moisture increases significantly the thermochemical exergy in the fuel streams and, hence, the exergy destruction in heat exchangers.

Figures 6C,D shows the contribution of each process unit in the total exergy destruction of the combined system at 80 and 95 wt.\% biomass moisture as a function of the $U_{f}$. The total exergy destruction of the combined system decreases with increasing $\mathrm{U}_{\mathrm{f}}$. The exergy destruction in the SCWG has almost no influence on the $\mathrm{U}_{\mathrm{f}}$. But the exergy destruction in the SOFCair preheater increases with increased $U_{f}$ because higher fuel utilization increases the heat produced by the SOFC. Thus, the more heat carried out the by air stream, the more power required to drive the air compressor CM2. Besides, the increase in air flow rate increases the exergy destruction in the air preheater heat exchangers, since the SOFC cathode air is recirculated and fed to the PSC (Figure 2). The exergy destruction in the SOFC increases slightly at increased $\mathrm{U}_{\mathrm{f}}$ as more fuel is processed. On the contrary, the exergy destruction in the PSC, fuel-preheater, and GUP decreases with increasing $U_{f}$. Higher fuel utilization reduces the fuel combusted in the PSC, hence, the stream available for fuel-preheater has less difference in temperature, and thus less exergy destruction. Similarly, the temperature of the stream fed the GUP is low and thus lower exergy destruction accompanying heat transfer. The exergy destruction in the SOFC at $95 \mathrm{wt} \%$ at increasing $\mathrm{U}_{\mathrm{f}}$ is lower than that 80 wt.\%. The higher concentration of $\mathrm{H}_{2}$ at higher moisture content increases the thermochemical exergy and reduces the exergy destruction.

The PSC produces heat at high temperature and at low $U_{f}$, which results in high exergy destruction in heat exchangers, affecting the performance of the SCWGSOFC combined system. The integration of the system, operating with biomass moisture lower than 90 wt.\%, with bottoming cycles to recover the heat is a subject for further simulations. 


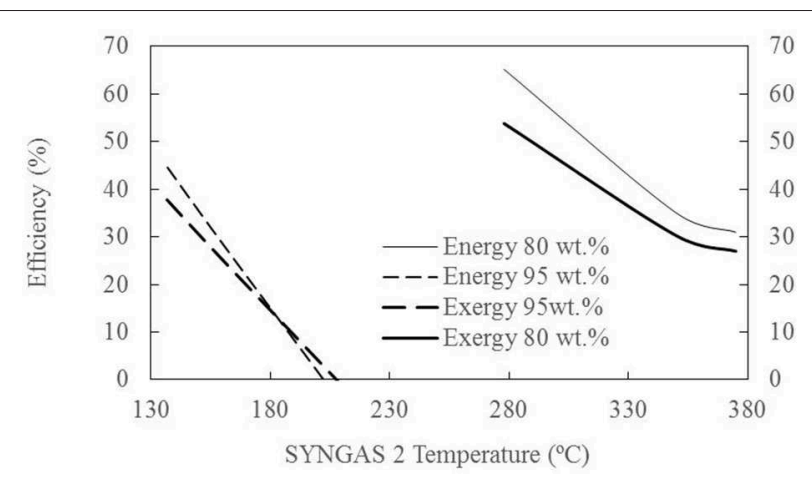

FIGURE 7 | Influence of the heat recovery on the supercritical water gasification (SCWG) solid oxide fuel cell (SOFC) efficiency.

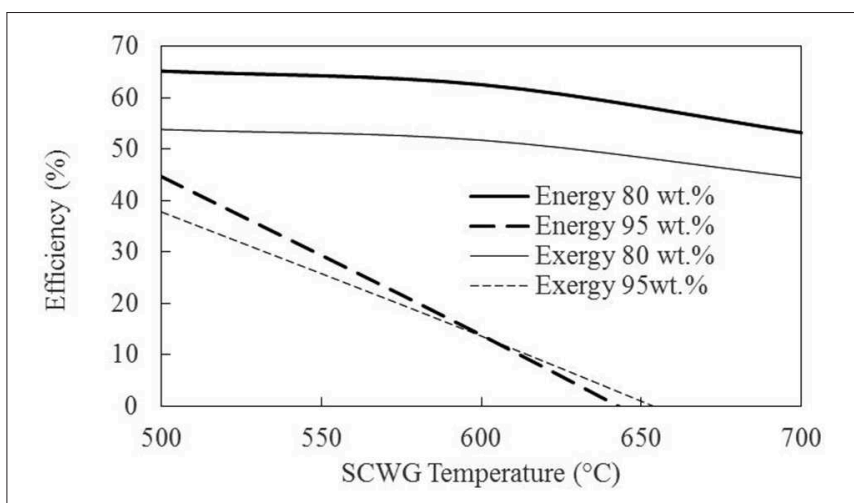

FIGURE 8 | System efficiency as a function of the gasifier temperature at 80 and 95 wt. \% moisture.

\section{Influence of SCWG Heat Recovery on the System Efficiencies}

The energy and exergy efficiency strongly depends on the heat recovery from the product gas generated in the SCWG. The heat exchanger HX2 recovers the heat from the stream GASPRO by heating the feed to the SCWG. The temperature of the hot stream SYNGAS2 reflects the amount of heat recovered (Figure 2). According to the design presented in the work of Fiori et al. (2012), the temperature of the stream SYNGAS2 maintains the vapor fraction equal to one at $350^{\circ} \mathrm{C}$. While in the work of Feng et al. (2004), the liquid fraction of the stream SYNGAS2 is equal to one at $100^{\circ} \mathrm{C}$. In this work, the estimation of the minimal temperature of SYNGAS2 depends on the process heat available. Figure 7 shows the influence of the SYNGAS2 temperature on system efficiency. At $80 \mathrm{wt} . \%$ biomass moisture, the maximum heat recovered is at SYNGAS2 temperature $278^{\circ} \mathrm{C}$, reaching energy and exergy efficiency of 65 and 53\%, respectively. At higher SYNGAS2 temperature $\left(375^{\circ} \mathrm{C}\right)$, less heat is recovered and the efficiencies decrease to 31 and $27 \%$. At 95 wt.\%, the minimum temperature is $137^{\circ} \mathrm{C}$, at high moisture, there is less process heat available. Higher SYNGAS2 temperature than $137^{\circ} \mathrm{C}$ makes the combined system no longer energetically sustainable since the system requires additional external heat for fuel preheating.

\section{Influence of the SCWG Operating Temperature on the System Efficiency}

The variations in the efficiencies of the combined SCWGSOFC system with the SCWG operating temperature and biomass moisture are presented in Figure 8 (at $U_{f} \quad 0.85$ ). The exergy and net electrical efficiencies decrease when the operating temperature increases, since high operating temperature increments the heat demanded by the gasifier, while the chemical exergy of the product gas slightly increases. At 80 wt.\%, the energy and exergy efficiencies reach a maximum of 65 and $54 \%$, respectively, at $500^{\circ} \mathrm{C}$. These are significantly higher than the efficiencies at $95 \mathrm{wt} . \%, 44$ and 37\%. The combination of high moisture and high temperature considerably reduces system efficiency. At operating temperatures higher than $650^{\circ} \mathrm{C}$ and 95 wt.\% the system is not self-sustainable. The power generated by

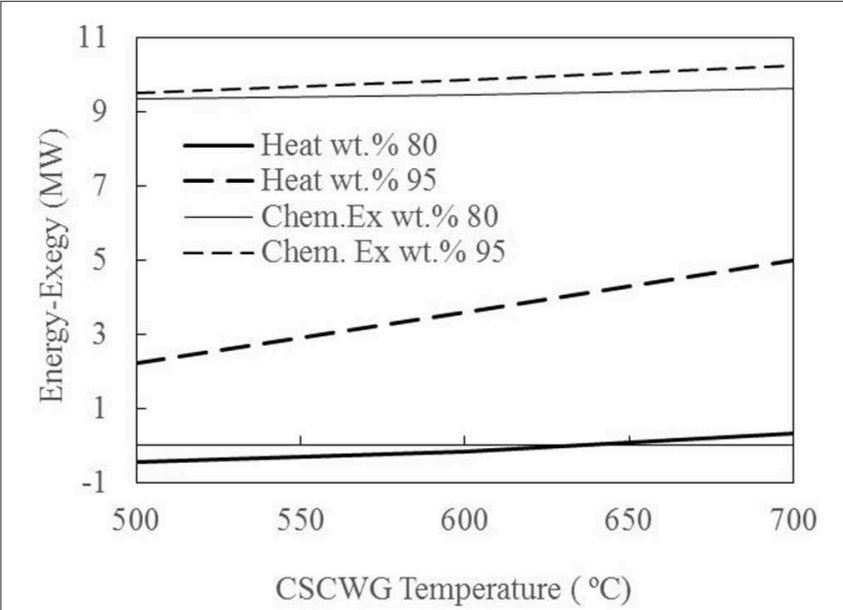

FIGURE 9 | Supercritical water gasification (SCWG) heat needed and chemical exergy of stream SYNGAS as a function of the gasifier temperature.

the SOFC is significantly lower than the total power consumption by the auxiliary components of the system due to the high energy demanded by the SCWG.

Figure 9 illustrates the variation in the heat needed by the SCWG and the chemical exergy variation of the product gas as a function of the gasifier temperature and biomass moisture. The chemical exergy of the product gas slightly increases with the temperature at 80 and $95 \mathrm{wt} . \%$. The SCWG is, to some extent, exothermic at lower temperature and low moisture. Since the exothermic reactions 3 and 4 are favorable, the gasifier requires less heat. The gasifier generates $0.5 \mathrm{MW}$ of heat at $500^{\circ} \mathrm{C}$ and 80 wt.\%. The heat demanded by the gasifier slightly increases with the temperature. At higher moisture levels, the gasifier is very endothermic. The heat needed by the SCWG at $95 \mathrm{wt} . \%$ and $500^{\circ} \mathrm{C}$ increases to $2.2 \mathrm{MW}$ and significantly increases with temperature to $5 \mathrm{MW}$ at $700^{\circ} \mathrm{C}$. At high moisture levels, the endothermic reactions 1 and 2 dominate, and because of the high moisture levels, the gasifier requires a higher amount of heat. 


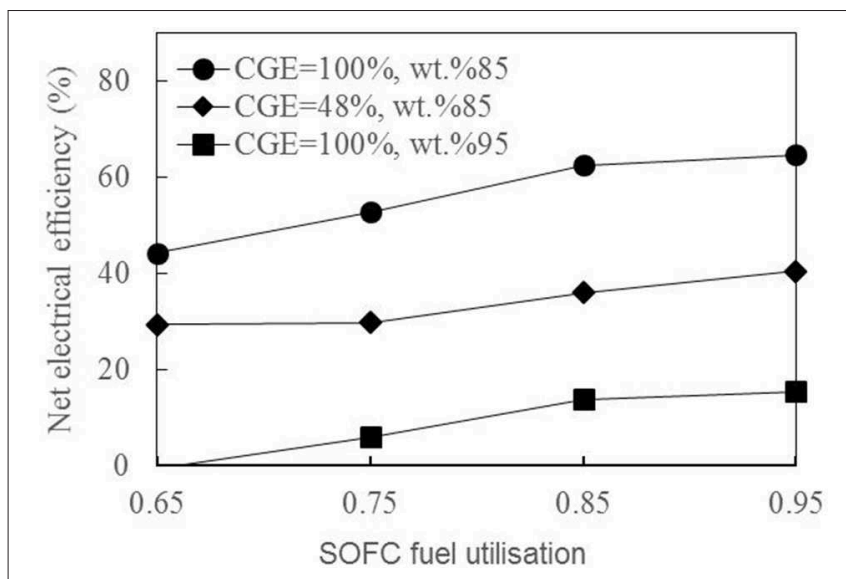

FIGURE 10 | System net electrical efficiency as a function of the $\bigcup_{f}$ at different gasifier carbon gasification efficiency (CGE).

Figure 6B shows the effects of SCWG temperature on the irreversibilities in the primary process units of the SCWG-SOFC combined system and their contributions to the total exergy destruction at $\mathrm{U}_{\mathrm{f}}$ 0.85. Higher temperatures increase the heat demanded by the gasifier; hence, the total exergy destruction in the system increases. The exergy destruction in the SOFC airpreheater accounts for the most substantial amount. The high temperature increases the $\mathrm{H}_{2}$ production, increasing the heat carried by the air stream. This increases the air flow rate and thus the thermochemical exergy and exergy destruction in the heat exchangers. Consequently, the exergy destruction in the PSC increases as well. The increased temperatures in the gasifier rises the exergy destruction in the GUP since the product gas fed to the GUP has a higher thermochemical exergy. On the other hand, the exergy destruction in the SOFC decreases with the increased gasifier temperature. High temperature favors an increment of $\mathrm{H}_{2}$ and decrement of $\mathrm{CH}_{4}$ in the gas product. Higher production of $\mathrm{H}_{2}$ in the gasifier reduces the requirement of heat in the SOFC for the endothermic $\mathrm{CH}_{4}$ internal reforming reaction. Thus, more heat is available in the SOFC to be utilized for air and fuel processing.

\section{Influence of the CGE of SCWG on the System Efficiency}

Figure 10 shows the net electrical efficiency of the SCWG-SOFC as a function of $\mathrm{U}_{\mathrm{f}}$ at gasifier GCE of $40 \%$ (non-thermodynamic equilibrium) and CGE of $100 \%$. The non-equilibrium process parameters are selected from available experimental data of SCWG of biomass, taking into account the projection to industrial application and considering the current technical and catalytic limitations to build a reactor. Dry biomass content is 15 wt. $\%, 600^{\circ} \mathrm{C}, 25 \mathrm{MPa}$. The gas concentration and CGE are assumed the same as the ones reported in the work of Lu et al. (2008) (Table 5).

At non-equilibrium, the efficiency reaches 29 to $40 \%$ at $\mathrm{U}_{\mathrm{f}}$ 0.65-0.95, which is significantly lower compared with the equilibrium calculations. The main reason is the
TABLE 5 | Key data and results from supercritical water gasification (SCWG) solid oxide fuel cell (SOFC).

\begin{tabular}{|c|c|c|}
\hline Process & SCWG-SOFC & $\begin{array}{l}\text { Plasma-assisted } \\
\text { two-stage gasifier } \\
\text {-SOFC-MST (Recalde } \\
\text { et al., 2018) }\end{array}$ \\
\hline Reactor & FBR & NA \\
\hline Temperature $\left({ }^{\circ} \mathrm{C}\right)$ & 600 & 950 \\
\hline Pressure (bar) & 250 & 1.013 \\
\hline Dry biomass flow rate $\mathrm{g} / \mathrm{s}$ & 0.56 & 0.56 \\
\hline Concentration (wt.\%) & 15 & 15 \\
\hline \multicolumn{3}{|l|}{ Gas composition (vol.\%) } \\
\hline $\mathrm{H}_{2}$ & 29 & 56 \\
\hline $\mathrm{CH}_{4}$ & 3 & 0 \\
\hline $\mathrm{CO}$ & 36 & 39.5 \\
\hline $\mathrm{CO}_{2}$ & 32 & 3.16 \\
\hline Carbon gasification (\%) & 40 & 100 \\
\hline Cold gas efficiency (\%) & 46 & 88 \\
\hline $\begin{array}{l}\text { Carbon concentration in } \\
\text { water soluble solvent }\end{array}$ & $>50 \%$ & 0 \\
\hline $\begin{array}{l}\text { Energy biomass input } \\
{[\mathrm{kW}](\mathrm{LHVdry})}\end{array}$ & 9.43 & 9.43 \\
\hline $\begin{array}{l}\text { SOFC net power } \\
\text { production [kWel] }\end{array}$ & 3.6 & 6.4 \\
\hline SOFC fuel utilization $U_{f}$ & $0.65-0.95$ & 0.5 \\
\hline $\begin{array}{l}\text { Energy auxiliary } \\
\text { components [kWel] }\end{array}$ & 0.2 & 0.54 \\
\hline Net electrical efficiency (\%) & $29-40$ & 63 \\
\hline
\end{tabular}

low CGE of the SCWG, in the order of $40 \%$, resulting in a high amount of unconverted biomass discharged in the GUP.

The net electrical efficiency is in the order of 44 to $65 \%$ at thermodynamic equilibrium and the SOFC operating at $U_{f}$ varying from 0.65 to 0.95 . According to experimental results from the literature, gasifier operating temperatures higher than $600^{\circ} \mathrm{C}$ can improve the CGE at dry biomass around $15 \mathrm{wt} . \%$, but materials restriction is still an impediment (Guo et al., 2007). Besides, the CGE at $600^{\circ} \mathrm{C}$ with the support of a catalyst can be close to $100 \%$ at dry biomass lower than $5 \mathrm{wt} \%$, but the gasifier requires careful design to avoid low conversion. This work finds a system efficiency of $14 \%$ at 95 wt. $\%, 600^{\circ} \mathrm{C}, \mathrm{U}_{\mathrm{f}}$ 0.85 (Figure 9). In spite of the low efficiency, if a complete conversion of biomass can be achieved at moisture 95 wt.\%, it represents an advantage. The gas product rich in $\mathrm{H}_{2} \mathrm{O}$ at SCW conditions is a valuable product. It can be integrated with a bottoming cycle and recover the thermochemical exergy of the product.

\section{GASIFIER-SOFC SYSTEM PERFORMANCE COMPARISON SCWG-SOFC Combined System}

The work of Toonssen et al. (2010), SCWG of 20 wt.\% (dry) manure content, at $600^{\circ} \mathrm{C}$ and $24 \mathrm{MPa}$, reported a net electrical 
efficiency of the order of $50 \%$. The gasifier is at equilibrium and $100 \%$ CGE; however, this is not yet possible to achieve with current technology at dry biomass content higher than 10 wt. $\%$.

\section{Competing Technologies}

Table 5 gives the necessary data of the SCWG-SOFC integrated system compared with the results of a dryer-plasma-assisted two-stage gasifier-SOFC-micro steam turbine (MST) combined system, as both systems are developed for similar purposes (production of electricity with high efficiency from wet biomass streams. According to thermodynamic calculations, the combination of a superheated steam dryer and plasma-assisted two-stage gasifier-gas cleaning unit (GCU)-SOFC-MST (Recalde et al., 2018) gives a net electrical efficiency of the order of 50$65 \%$. The system is fed with biomass at 60-92 wt.\% moisture. The syngas contains a higher amount of $\mathrm{H}_{2}$ and $\mathrm{CO}$ and a lower amount of $\mathrm{CO}_{2}$ than the gas product in SCWG. The gasifier is at equilibrium, and $100 \%$ of the carbon is gasified. The cold gas efficiency, which is the chemical energy of the syngas as a proportion of the chemical energy of the biomass and energy input to the gasifier is $88 \%$.

Thermodynamic calculations and experiments demonstrate that a CGE near $100 \%$ is possible with a plasma-assisted two-stage gasifier. The gasifier receives additional energy from the plasma torch. The moisture content of the biomass, higher than $90 \mathrm{wt} . \%$, is not a barrier to reach system efficiency higher than $50 \%$, with the application of an efficient dryer unit. The integrated system constituted with a drier, plasma-assisted two-stage gasifier, GCU, SOFC, and MST is relatively complex and needs further technology development and experimental demonstration.

In contrast, the limited results available from SCWG thermodynamic calculations or experiments demonstrate the possibility to reach a CGE near $100 \%$ utilizing real biomass at dry biomass content higher than $10 \mathrm{wt} . \%$. High CGE is only possible to achieve at dry biomass content lower than 10 wt.\%. However, the SCWG-SOFC is not energetically suitable at this concentration. Furthermore, the product stream contains relatively high $\mathrm{CO}_{2} \quad(>20$ vol\%). The generation of high amounts of water-soluble compounds ( $>40 \mathrm{wt} \%$ ) at dry biomass higher than 10 wt.\% is responsible for the significantly low system efficiencies.

However, this study reveals that the optimal combination of the operational conditions of the SCWG-SOFC system could make the integrated system more competitive. The process streams may combine thermal power plants. Besides, an advantage of the SCWG is the production of a stream rich in steam at high temperature and pressure; the energy of this stream can be recovered with more efficient methods. In the current system, this energy is not recovered entirely due to heat transfer limitations, which also influence the efficiency of the system. The products generated in the real SCWG gasifier, $\mathrm{CO}_{2}$, steam, and water-soluble compounds could be utilized in different processes, for example, the electrochemical reduction of $\mathrm{CO}_{2}$ and $\mathrm{H}_{2} \mathrm{O}$ into $\mathrm{CO}, \mathrm{H}_{2}$, and $\mathrm{O}_{2}$ when excess electrical energy is available (Recalde et al., 2017). The reforming or partial oxidation of the water-soluble compounds is also a possibility to produce more useful products. Those are methods that may make both systems appear as appealing but face challenges.

\section{CONCLUSIONS}

A thermodynamic model is developed in Aspen Plus ${ }^{\mathrm{TM}}$ to evaluate the performance of the SCWG-SOFC combined system. The gasifier model is considered first at thermodynamic equilibrium and subsequently at non-equilibrium. The model assesses the effect of several gasifier operating parameters and the SOFC $\mathrm{U}_{\mathrm{f}}$ on the net electrical and exergy efficiencies, as well as on the total and process unit wise exergy destruction.

The SCWG operating parameters varied are temperature, biomass moisture, residence time, and the percentage conversion of biomass in the gasifier. Thermodynamic equilibrium simulation of SCWG assuming a CGE is equal to $100 \%$ results in higher system efficiency. However, near 100\% conversion of real biomass into a gas product in SCWG is only possible at solid contents lower than $10 \mathrm{wt} \%$ at temperatures higher than $500^{\circ} \mathrm{C}$ and long residence times. However, due to the operating conditions, there are material limitations and difficulties in the reactor construction. Besides, at low solid content, the remarkably high energy needed to increase the temperature of the water reduces the energetic sustainability of the combined system. At 95 wt. $\%$ moisture, $600^{\circ} \mathrm{C}, 250$ bar, $\mathrm{U}_{\mathrm{f}} 0.85$, the net electrical efficiency is $14 \%$ at thermodynamic equilibrium. Nevertheless, the almost full biomass conversion at these conditions make the SCWG product gas suitable for using in bottoming cycles as a way to increase the system efficiencies.

Dry biomass contents higher than $10 \mathrm{wt}$.\% gives higher net electrical efficiency. However, near 100\% biomass conversion into product gas is not found experimentally for higher dry biomass content in SCWG systems. At these conditions, the CGE is around $40 \%$, the combined system net electrical efficiency reduces to 29 and $40 \%$ at SOFC fuel utilization of 0.65 and 0.95 , respectively, fed with biomass, with a solid content of 15 wt. $\%$ at $600^{\circ} \mathrm{C}$ and $25 \mathrm{MPa}$. The low conversion of the solid biomass into product gas in a real SCWG and the low heating value of syngas $\left(\mathrm{CO}_{2}>20\right.$ vol\%) are the main reasons for the low net electrical efficiency of the SCWG- SOFC systems. The product gas composition of the SCWG reactor is from reported experimental data, where the gasifier has not reached thermodynamic equilibrium. On the contrary, at thermodynamic equilibrium, the system reaches a higher net electrical and exergy efficiency of 63 and $52 \%$, respectively, at $\mathrm{U}_{\mathrm{f}}=0.85$ for the SOFC and $600^{\circ} \mathrm{C}$ and $25 \mathrm{MPa}$ in the gasifier for a dry biomass content of 20 wt.\%. The SOFC-air preheater causes the highest exergy destruction. The lower moisture results in excess thermochemical exergy available in the system for using in bottoming cycles, and this could improve the system efficiency.

A potential exists for improving the gasification process by employing a suitable catalyst and increasing the residence time and materials quality, and so on. Such improvements, though not easy to achieve, might lead to efficient gasifiers and efficient systems. On the other hand, the variation of operational parameters such as biomass moisture content, SCWG operating 
temperature, SOFC fuel utilization generates process stream. That has a high potential for its integration with other processes. Thus, in spite of the engineering limitations of the SCWG, the performance of the combined system can be improved. In this regard, the product gas rich in steam and $\mathrm{CO}_{2}$ obtained at high biomass moisture in the gasifier can be integrated with an electrochemical process to produce fuel. While at low biomass moisture, the high heat produced combined with bottoming cycles, such as thermal power plants, is a route to improve the system performance. The water-soluble compounds generated in the SCWG process, being useful by-products, might also increase the competitiveness of real SCWG systems.

It is also interesting to note that alternative approaches are being proposed for power generation from very wet biomass streams. For example, the previous paper from the authors of this manuscript describes a system based on plasma gasification (Recalde et al., 2017). However, such systems also need further technology development as it is the case with SCWG-based systems. Given the importance of the challenge, multiple technology lines should be pursued in parallel.

\section{REFERENCES}

Aspen Plus (2012). Getting Started Modeling Processes with Solids Aspen Plus, Toll Free. Available online at: https://www.coursehero.com/file/41381596/ Aspen-reference-1pdf/

Basu, P., and Mettanant, V. (2009). Biomass gasification in supercritical water - a review. Int. J. Chem. React. Eng. 7, 1542-6580. doi: 10.2202/1542-6580.1919

Behnia, I., Yuan, Z., Charpentier, P., and Xu, C. (2016). Production of methane and hydrogen via supercritical water gasification of renewable glucose at a relatively low temperature: effects of metal catalysts and supports. Fuel Process. Technol. 143, 27-34. doi: 10.1016/j.fuproc.2015.11.006

Boukis, N., Hauer, E., Herbig, S., Sauer, J., and Vogel, F. (2017). Catalytic gasification of digestate sludge in supercritical water on the pilot plant scale. Biomass Convers. Biorefinery. 7, 415-424. doi: 10.1007/s13399-017-0238-X

Chen, Y., Guo, L., Cao, W., Jin, H., Guo, S., and Zhang, X. (2013). Hydrogen production by sewage sludge gasification in supercritical water with a fluidized bed reactor. Int. J. Hydrogen Energy 38, 12991-12999. doi: 10.1016/j.ijhydene.2013.03.165

Chen, Y., Wang, M., Liso, V., Samsatli, S., Samsatli, N. J., Jing, R., et al. (2019). Parametric analysis and optimization for exergoeconomic performance of a combined system based on solid oxide fuel cell-gas turbine and supercritical carbon dioxide Brayton cycle. Energy Convers. Manage. 186, 66-81. doi: 10.1016/j.enconman.2019.02.036

European Commission (2015). European Commission, 2030 Energy Strategy. Eur. Comm. Available online at: https://ec.europa.eu/energy/en/topics/energystrategy-and-energy- union/2030-energy-strategy (accessed February 1, 2018).

Facchinetti, E., Gassner, M., D’Amelio, M., Marechal, F., and Favrat, D. (2012). Process integration and optimization of a solid oxide fuel cell - Gas turbine hybrid cycle fueled with hydrothermally gasified waste biomass. Energy 41, 408-419. doi: 10.1016/j.energy.2012.02.059

Feng, W., Van Der Kooi, H. J., and De Swaan Arons, J. (2004). Biomass conversions in subcritical and supercritical water: driving force, phase equilibria, and thermodynamic analysis. Chem. Eng. Process. Process Intensif. 43, 1459-1467. doi: 10.1016/j.cep.2004.01.004

Fiori, L., Valbusa, M., and Castello, D. (2012). Supercritical water gasification of biomass for $\mathrm{H}_{2}$ production: process design. Bioresour. Technol. 121, 139-147. doi: 10.1016/j.biortech.2012.06.116

Gökkaya, D. S., Saglam, M., Yuksel, M., and Ballice, L. (2016). Hydrothermal gasification of xylose: effects of reaction temperature, pressure, and $\mathrm{K} 2 \mathrm{CO} 3$ as a catalyst on product distribution. Biomass Bioenergy 91, 26-36. doi: 10.1016/j.biombioe.2016.04.013

\section{DATA AVAILABILITY STATEMENT}

All datasets generated and analyzed for this study are included in the manuscript.

\section{AUTHOR CONTRIBUTIONS}

PA contributed conception of the study and examined model results and text. TW analyzed the thermodynamic models and contributed to the discussions. MR carried out the thermodynamic analysis and prepared the first draft and final version of the paper. TW and PA contributed to manuscript revision and additionally read, corrected, and approved the submitted version.

\section{ACKNOWLEDGMENTS}

The authors thank the Ecuador Secretaría de Educación Superior, Ciencia, Tecnología e Innovación (SENESCYT) for financial support regarding a Fellowship Ph.D. program.

Guo, L. J., Lu, Y. J., Zhang, X. M., Ji, C. M., Guan, Y., and Pei, A. X. (2007). Hydrogen production by biomass gasification in supercritical water: A systematic experimental and analytical study. Catal. Today 129, 275-286. doi: 10.1016/j.cattod.2007.05.027

Guo, Y., Wang, S. Z., Xu, D. H., Gong, Y. M., Ma, H. H., and Tang, X. Y. (2010). Review of catalytic supercritical water gasification for hydrogen production from biomass. Renew. Sustain. Energy Rev. 14, 334-343. doi: 10.1016/j.rser.2009.08.012

Hanna, J., Lee, W. Y., Shi, Y., and Ghoniem, A. F. (2014). Fundamentals of electro- and thermochemistry in the anode of solid-oxide fuel cells with hydrocarbon and syngas fuels. Prog. Energy Combust. Sci. 40, 74-111. doi: 10.1016/j.pecs.2013.10.001

He, C., Chen, C. L., Giannis, A., Yang, Y., and Wang, J. Y. (2014). Hydrothermal gasification of sewage sludge and model compounds for renewable hydrogen production: a review. Renew. Sustain. Energy Rev. 39, 1127-1142. doi: 10.1016/j.rser.2014.07.141

Ibram, G. (2018). "Chapter 4: The electrochemical conversion of carbon dioxide to carbon monoxide over nanomaterial based cathodic systems: measures to take to apply this laboratory process industrially," in Applications of Nanomaterials: Advances and Key Technologies, eds S. M. Bhagyaraj, O. S. Oluwafemi, N. Kalarikkal, and S. Thomas (Cambridge, MA: Woodhead Publishing), 83-131. doi: 10.1016/B978-0-08-101971-9.00005-3

Ilbaş, M., and Kümük, B. (2019). Modeling and analysis of a model solid oxide fuel cell running on low calorific value coal gases. Int. J. Hydrogen Energy. doi: 10.1016/j.ijhydene.2019.01.286. [Epub ahead of print].

Kozeschnik, E. (2000). A numerical model for evaluation of unconstrained and compositionally constrained thermodynamic equilibria. Calphad Comput. Coupling Phase Diagrams Thermochem. 24, 245-252. doi: 10.1016/S0364-5916(01)00003-7

Kruse, A. (2008). Supercritical water gasification. Biofuels Bioprod. Biorefining. 2, 415-437. doi: 10.1002/bbb.93

Kruse, A., and Dinjus, E. (2005). Influence of salts during hydrothermal biomass gasification: the role of the catalysed water-gas shift reaction. Zeitschrift Fur. Phys. Chemie 219, 341-366. doi: 10.1524/zpch.219.3.341.59177

Kruse, A., and Faquir, M. (2007). Hydrothermal biomass gasification-effects of salts, backmixing, and their interaction. Chem. Eng. Technol. 30, 749-754. doi: 10.1002/ceat.200600409

Lu, Y. J., Jin, H., Guo, L. J., Zhang, X. M., Cao, C. Q., and Guo, X. (2008). Hydrogen production by biomass gasification in supercritical water with a fluidized bed reactor. Int. J. Hydrogen Energy. 33, 6066-6075. doi: 10.1016/j.ijhydene.2008.07.082 
Maurice Henri, W. (2007). Catalytic Hydrothermal Gasification of Biomass for the Production of Synthetic Gas. Richland,WA: ETH Zurich, Wiley.

Moran, M. J. (2017). "Engineering thermodynamics: fundamentals," $C R C$ Handbook of Thermal Engineering, 2nd Edn., ed R. P. Chhabra (Boca Raton, FL: CRC Press), 3-14.

O’Hayre, R., Cha, S.-W., Colella, W., Prinz, F. B. (2016). "Chapter 2: Fuel cell thermodynamics," in Fuel Cell Fundamentals (Hoboken, NJ: John Wiley \& Sons, Inc.).

Oka, Y., and Koshizuka, S. (2001). Supercritical-pressure, once-through cycle light water cooled reactor concept. J. Nucl. Sci. Technol. 38, 1081-1089. doi: 10.1080/18811248.2001.9715139

Oka, Y., and Koshizuka, S. I. (1993). Concept and design of a supercriticalpressure, direct-cycle light-water reactor. Nucl. Technol. 103, 295-302. doi: 10.13182/NT93-A34852

Peterson, A. A., Vogel, F., Lachance, R. P., Fröling, M., Antal, M. J., and Tester, J. W. (2008). Thermochemical biofuel production in hydrothermal media: a review of sub- and supercritical water technologies. Energy Environ. Sci. 1, 32-65. doi: 10.1039/b810100k

Recalde, M., Botta, G., Fernandes, A., Woudstra, T., and Aravind, P.V. (2017). Modelling of a novel catalytic supercritical water gasification power plant combined with reversible solid oxide cell. ECS Trans. 78, 2997-3007. doi: $10.1149 / 07801.2997$ ecst

Recalde, M., Woudstra, T., and Aravind, P. V. (2018). Renewed sanitation technology: a highly efficient faecal-sludge gasification-solid oxide fuel cell power plant. Appl. Energy. 222, 515-529. doi: 10.1016/j.apenergy.2018.03.175

Rodriguez Correa, C., and Kruse, A. (2018). Supercritical water gasification of biomass for hydrogen production - Review. J. Supercrit. Fluids. 133, 573-590. doi: 10.1016/j.supflu.2017.09.019

Santarelli, M., Briesemeister, L., Gandiglio, M., Herrmann, S., Kuczynski, P., Kupecki, J., et al. (2017). Carbon recovery and re-utilization (CRR) from the exhaust of a solid oxide fuel cell (SOFC): analysis through a proof-of-concept. J. $\mathrm{CO}_{2}$ Util. 18, 206-221. doi: 10.1016/j.jcou.2017.01.014

Schuster-Wallace, C. J., Wild, C., and Metcalfe, C. (2015). Valuing Human Waste as an Energy Resource, a Research Brief Assessing the Global Wealth in Waste. Environment and Health (UNU-I. University, United Nations, Institute for Water). Available online at: http://inweh.unu.edu

Tanim, T., Bayless, D. J., and Trembly, J. P. (2013). Modeling of a $5 \mathrm{~kW}$ e tubular solid oxide fuel cell based system operating on desulfurized JP-8 fuel for auxiliary and mobile power applications. J. Power Sources. 221, 387-396. doi: 10.1016/j.jpowsour.2012.08.024

Tanim, T., Bayless, D. J., and Trembly, J. P. (2014). Modeling a $5 \mathrm{~kW}$ e planar solid oxide fuel cell based system operating on JP-8 fuel and a comparison with tubular cell based system for auxiliary and mobile power applications. J. Power Sources. 245, 986-997. doi: 10.1016/j.jpowsour.2013. 07.008

Tekin, K., Karagöz, S., and Bektaş, S. (2014). A review of hydrothermal biomass processing. Renew. Sustain. Energy Rev. 40, 673-687. doi: 10.1016/j.rser.2014.07.216

Toonssen, R., Aravind, P. V., Smit, G., Woudstra, N., and Verkooijen, A. H. M. (2010). System study on hydrothermal gasification combined with a hybrid solid oxide fuel cell gas turbine. Fuel Cells 10, 643-653. doi: $10.1002 /$ fuce. 200900188

Toor, S. S., Rosendahl, L., and Rudolf, A. (2011). Hydrothermal liquefaction of biomass: a review of subcritical water technologies. Energy. 36, 2328-2342. doi: 10.1016/j.energy.2011.03.013
Tushar, M. S. H., Dutta, A., Xu, C. (2015). Simulation and kinetic modeling of supercritical water gasification of biomass. Int. J. Hydrogen Energy. 40, 4481-4493. doi: 10.1016/j.ijhydene.2015.02.033

$\mathrm{Xu}, \mathrm{Z}$. R., Zhu, W., and Li, M. (2012). Influence of moisture content on the direct gasification of dewatered sludge via supercritical water. Int. J. Hydrogen Energy 37, 6527-6535. doi: 10.1016/j.ijhydene.2012.01.086

Yakaboylu, O. (2016). Supercritical Water Gasification of Wet Biomass and Experiments. Delft: University of Technology.

Yakaboylu, O., Albrecht, I., Harinck, J., Smit, K. G., Tsalidis, G. A., Di Marcello, M., Anastasakis, K., and de Jong W. (2018). Supercritical water gasification of biomass in fluidized bed: first results and experiences obtained from TU Delft/Gensos semi-pilot scale setup. Biomass and Bioenergy. 111, 330-342. doi: 10.1016/j.biombioe.2016.12.007

Yakaboylu, O., Harinck, J., Smit, K. G., and De Jong, W. (2015a). Testing the constrained equilibrium method for the modeling of supercritical water gasification of biomass. Fuel Process. Technol. 138, 74-85. doi: 10.1016/j.fuproc.2015.05.009

Yakaboylu, O., Harinck, J., Smit, K. G., and de Jong, W. (2015b). Supercritical water gasification of biomass: a literature and technology overview. Energies 8, 859-894. doi: 10.3390/en8020859

Yakaboylu, O., Harinck, J., Smit, K. G., and De Jong, W. (2015d). Supercritical water gasification of biomass: a detailed process modeling analysis for a microalgae gasification process. Ind. Eng. Chem. Res. 54, 5550-5562. doi: 10.1021 /acs.iecr.5b00942

Yakaboylu, O., Yapar, G., Recalde, M., Harinck, J., Smit, K. G., Martelli, E., et al. (2015c). Supercritical water gasification of biomass: an integrated kinetic model for the prediction of product compounds. Ind. Eng. Chem. Res. 54, 8100-8112. doi: $10.1021 /$ acs.iecr.5b02019

Yan, Z., Zhao, P., Wang, J., and Dai, Y. (2013). Thermodynamic analysis of an SOFC-GT-ORC integrated power system with liquefied natural gas as heat sink. Int. J. Hydrogen Energy 38, 3352-3363. doi: 10.1016/j.ijhydene.2012.12.101

Zhang, L., Champagne, P., and Charles Xu, C. (2011b). Supercritical water gasification of an aqueous by-product from biomass hydrothermal liquefaction with novel Ru modified Ni catalysts. Bioresour. Technol. 102, 8279-8287. doi: 10.1016/j.biortech.2011.06.051

Zhang, L., Champagne, P., and Xu, C. (2011a). Screening of supported transition metal catalysts for hydrogen production from glucose via catalytic supercritical water gasification. Int. J. Hydrogen Energy 36, 9591-9601. doi: 10.1016/j.ijhydene.2011.05.077

Zhang, W., Croiset, E., Douglas, P. L., Fowler, M. W., and Entchev, E. (2005). Simulation of a tubular solid oxide fuel cell stack using AspenPlus $^{\mathrm{TM}}$ unit operation models. Energy Convers. Manag. 46, 181-196. doi: 10.1016/j.enconman.2004.03.002

Conflict of Interest: The authors declare that the research was conducted in the absence of any commercial or financial relationships that could be construed as a potential conflict of interest.

Copyright (c) 2019 Recalde, Woudstra and Aravind. This is an open-access article distributed under the terms of the Creative Commons Attribution License (CC BY). The use, distribution or reproduction in other forums is permitted, provided the original author(s) and the copyright owner(s) are credited and that the original publication in this journal is cited, in accordance with accepted academic practice. No use, distribution or reproduction is permitted which does not comply with these terms. 


\section{NOMENCLATURE}

BOP

CGE

E

$\dot{e}_{f}$

$\overline{\mathrm{ex}}_{i}^{\mathrm{ch}}$

$\dot{E}_{d}$

F

$\Delta G$

GUP

$\Delta \mathrm{H}$

h

j

LHV

$\dot{m}$

$\dot{N}$

PSC

$\dot{p}$

$\dot{P}_{S O F C}$

$\dot{P}_{B O P}$

$\triangle S$

$S$

$\cup_{f}$

$\mathrm{V}_{\text {SOFC }}$

Greek letters

Subscripts

act

conc

e

ex

j

ohm

ox

sys

balance of the plant

carbon gasification efficiency

voltage $(\mathrm{V})$

specific flow exergy per unit of $\mathrm{mol}\left(\mathrm{kJ} \mathrm{mol}^{-1}\right)$

exergy (kW)

chemical exergy $\left(\mathrm{kJ} \mathrm{mol}^{-1}\right)$

exergy destruction rate $(\mathrm{kW})$

Faraday constant $\left(\mathrm{Cmol}^{-1}\right)$

change in specific molar Gibbs free energy $\left(\mathrm{Jmol}^{-1}\right)$

gas upgrading unit

change in specific molar enthalpy $\left(\mathrm{Jmol}^{-1}\right)$

specific enthalpy $\left(\mathrm{kJ} \mathrm{kg}^{-1}\right)$

current (A)

current density $\left(\mathrm{Acm}^{-2}\right)$

lower heating value $\left(\mathrm{kJmol}^{-1}\right)$

mass $\left(\mathrm{kg} \mathrm{s}^{-1}\right)$

number of moles

mole flow rate $\left(\mathrm{mol} \mathrm{s}^{-1}\right)$

post-combustor

partial pressure

power (kW)

power of the fuel cell $(\mathrm{kW})$

power of the auxiliary components $(\mathrm{kW})$

change in specific molar entropy $\left(\mathrm{KJ} \mathrm{mol} \mathrm{K}^{-1}\right)$

specific entropy $\left(\mathrm{KJ} \mathrm{K} \mathrm{kg}^{-1}\right)$

temperature $(\mathrm{K})$

fuel utilization ratio

voltage of the fuel cell $(\mathrm{V})$

mole fraction

efficiency

activation

concentration

exit

exergy

inlet, mixture components

number of components present in a mixture

ohmic

oxidant

reversible

system 